PLANTS OF MONROE COUNTY, NEW YORK AND ADJACENT TERRITORY.

SECOND SUPPLEMENTARY LIST.

$\mathrm{BY}$

Florence Beckwith, Mary E. Macauley and

Milton S. BAXTER,

Committee of the Botanical Section.

HYMENOMYCETEAE OF ROCHESTER AND VICINITY, BY

Fred S. Boughton.

ROCHESTER, N. Y.

Published by the Society. MAY, 1917. 



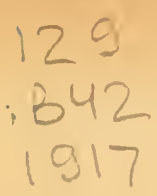

PROCEEDINGS OF THE ROCHESTER ACADEMY OF SCIENCE

VOL. 5, PP. 59-121.

MAY, 1917.

\section{PLANTS OF MONROE COUNTY, NEIT YORK, AND \\ ADJACENT TERRITORY.}

\section{SECOND SUPPLEAIENTARY LIST.}

By Flokence Beckwith, Mary E. Macauley and

MILTON S. BAXTER,

Committee of the Botanical Section.

CONTENTS.

Explanation,

Territury included,

Introduction of spe-ies.

New species,

Rediscovery of species.

foteworthy Trees by Jolin Dumbar.

Statistics,

The Catalogue,

Explanation of l,a i.

List of Pteridophyta.

Spermatophyta.

Index to Orders and Genera.

\section{EXPLANATION.}

In 1896 the Botanical Section of the Rochester Academy of Science published its first list of the "Plants of Monroe County, New York, and Adjacent Territory," the result of labors extending over many years.

In May, 1910, a "Supplementary List" was published covering the same territory, adding 225 new species and giving about one luundred new stations for plants which were considered rare or scarce. Since the issuing of the second list so many new species have been discovered by the members of the Section, and so many 1:ew stations for rare and scarce plants disclosed, that the publication of another Supplementary List has been deemed advisable. This list has been compiled from the records of the Section, and only such plants are included as have been identified by experts, and of which specimens are available for verification in the collections 
of the Academy and of the Park Commission at Rochester, in the State Herbarium at Albany, the National Herbarium at Washington, or in private collections of the members. Our acknowledgments are due to the State Botanist and to several members of the staff of the National Herbarium for their kindness in the identification of species.

In Rochester and vicinity many trees remarkable for size, beauty of form or rarity are to be found. Mr. John Dunbar, Assistant Superintendent of Parks, whose knowledge of the trees of the region is widespread and thorough, kindly consented to describe some of the most noteworthy specimens and give their locations.

Mr. Fred S. Boughton, a member of the Botanical Section, has devoted several years of study to the Hymenomycetex of Rochester and some of the adjoining towns, and the results of his labors are given in a list following that of the flowering plants. Mr. Boughton is a close and indefatigable student, and his labors have been recognized by having his name given to two new species which he discovered, one in the Adirondacks and the other in Monroe county: Lactarius Boughtonii Pk. and Hypholoma Boughtonii Pk.

\section{TERRitory INCLUDED.}

The territory included covers the same area as the lists of 1896 and 1910, comprising the whole of Monroe county and parts of Genesee, Livingston, Ontario, Orleans and Wayne counties, being in general the lower drainage basin of the Genesee river, with that of Irondequoit creek and smaller streams upon the lake border. Localities in Ontario county which had not been thoroughly explored previously, have within the last two years been visited many times by our members, and, in consequence, a number of new species and several new stations for rare and scarce plants have been added tc our list.

\section{INTRODUCTION OF SPECIES.}

The number of introduced species is increasing rapidly every year. Nany of these introductions are western plants and are found along the railroad tracks, which have been quite regularly patrolled by some of our nembers every season. 
In the summer of 1909 several species of plants foreign to our flora were found at Highland Park, in the southern part of the city. These plants were growing on newly seeded portions of the park. The grass seed used in sowing these places had been purchased from several different dealers and then mixed, so it was impossible to trace its origin, but the new species were mostly western plants.

The same stock of grass seed was used for seeding the slopes of the Cobb's Hill reservoir, then lately completed, and the following year a large number of new species of plants were found thriving vigorously in this new home. Through the kindness of Mr. C. C. Laney, Superintendent of Parks, these new plants were allowed to grow unmolested, and they increased in number and variety until 36 species foreign to our district had been found around the reservoir and at Highland Park.

After a few years it became impracticable to allow the grass on the slopes of the reservoir to remain uncut. For at least three or four years mowers have been regularly run over the ground and the plants have had to try to hold their own and make their way as best they could. It speaks well for their sturdiness and persistence that the majority of them have retained their hold and still survive. During the summer of 1916 representatives of nearly all the new species were found growing in more or less vigor, although, as a result of their being so frequently decapitated, many of them have not been allowed to blossom and so have not increased in abundance. Occasionally some in a favored location, close to a protecting tree or shrub, or on the steep sides of the reservoir where they have escaped the sharp teeth of the mowers, still not only survive but bloom quite freely. As it seems unlikely that any of them will ever become pernicious weeds, it is hoped that no particular pains will be taken to eradicate then, and that they will be allowed to live and thrive, for it adds interest to our flora to have these far western plants domesticated here.

The following list gives the names of these foreign species, al? of them determined by the State Botanist, and all represented in the herbarium of the Acadeny, or the State herbarium, or in the collections of the members of the Potanical Section: 
Stipa comata Trin. \& Rup.

Bonteloua oligostachy'a (Nutt.) Torr.

Hordemm jubatmm L.

Atriplex rosea L.

Chrysothammis pinifolins Greene

Ocnothera pallida Lindl.

Verbena bracteosa Michx.

Grindelia squarrosa (Pursh) Dunal

" " var. mada A. Gray

Chrysothammus pinifolins Greene

Guticresia Sarothrac Britton \& Rusby

Sideranthus gracilis (Nutt.) Rydb.

Aster mulliflorus Ait.

Machacranthera tanacotifolia (H. B. K.) Nees

“ pulierulenta (Nutt.) Greene

Gymnolomia multiflora (Nutt.) Benth. \& Hook.

Heliunthus petiolaris Nutt.

Lychnis alba Mill.

Lobnlaria maritima (L.) Desv.

Sisymbrimm Soplia L.

Anthyllis a'nlueraria $\mathrm{L}$.

Erodium cicutarimm $\mathrm{L}$.

Bidens tenuisecta A. Gray

Chacnactis sterioides Hook. \& Arn.

Dyssodia papposa (Vent.) Hitch.

Artemisia dracunculoides Pursh

“ glanca Pall.

" filifolia Torr.

" frigida Milld.

" liemis Milld.

“. guaphaloides Nutt.

“. trifida Nutt.

" carruthi llood

Senccio eremophilus Rich.

Carduns crispus L.

Lygodesmia erigua A. Gray. 
Epilobium hirsulum L. Was first found on the tracks of the New York Central railroad near Bergen in 1913. In $191+$ it was found in a swamp two or three miles north of Scottsville; in 1915 in the southern part of the village of Seottsville: in 1416 in Rochester, Menrlon and various other places, showing how rapidly new plants are disseminated.

I number of plants which were noted as rare or searce in our previous lists, are now reported from various stations. Notably among these is Serapias Helleborine L. LEpipactis Helleborine Gray. I In our list of 1896 one station was given for it, the third reported in the State. In the Supplenentary List, published in 1910, five new stations were reported, but it was still considered scarce. In the present list four more stations are given, and, in fact, it is being found in so many places that we are beginning to consider it almost common.

Sisymbrimm allissimmm L., first given in our list of 1910, has become so plentiful as to be considered pestiferous.

\section{New SPECiEs.}

In the Seventh Edition of (iray's botany many genera have been entirely revised, resulting in the adtition of numerous species. This has afforded an opportunity for the critical study of several of our common genera, and has shown that in on territory a larg:e percentage of the new species are present. This is notably the ease in the genus Viola, to which 11 new species have been aded, and to the genus Intennaria, which now includes 8 species, instead of the single one of our former list. ()ther genera, to a less degree, have also been studied with like results, and it is believed that continued investigation will show the presence of many species not yet inclurled in our lists.

The studies on Crataegus, Carya and Malus have been continued by Messrs. Dunbar, Slavin, Brown, Baxter and Dewing, and many species from this locality have been described by Dr. Sargent. References to the original publications are given with the species. Twenty-three new species of Crataegus and nine new Carya are given in the present list. 


\section{Rediscoveri of Species.}

In our list of 1896 a number of species were noted which had not been reported for several years. Some of these have since been rediscovered. Gentiana puberula Nichx. was found at Pushnell's Basin in 1914, only to have the station entirely destroyed before another year. Buchnera Americana L. has been found in two localities. Spiraca tomentosa L. has been discovered in Simpson's woods. Abies balsamea Mill. was found at Springwater and Gulick, Ontario county. Although these are not in all cases the original stations, it shows that the species noted are still to be found within our territory, and it is possible that others which have not been reported of late years will be brought to light by the persistent search of our botanists.

\section{Noteworthy Trees in Rochester and Vicinity.}

$$
\text { By JOHN DUNBar. }
$$

During the past sixty to seventy years the city of Rochester has been an important nursery center. A number of progressive nurserymen introduced many trees from various foreign sources to be tested in their grounds and sold to customers if they proved to be sufficiently hardy. The firm of Ellwanger \& Barry did a great cleal of work, at great expense, in introducing, testing and distribut ing many interesting trees from various parts of the world, and many of these are now to be seen in the City of Rochester and vicinity.

The Valley of the Genesee in the vicinity of Rochester is particularly adapted, through favorable climatic conditions, for growing many of the hardy trees of the north temperate zone. For example, the Chinese Magnolias, and hybrids derived from these Magnolias, grow with remarkable success in Rochester and vicinity. Perhaps there is no other city in the northeastern United States where these Magnolias grow any more freely. Panlownia imporialis, Sieb. \& Zucc., from China and Japan, is well known to be a tender tree and fails in many parts of the northern United States, but it succeeds very well in Rochester. 
The purpose of this paper is to record some of the most notable foreign trees in Rochester and ricinity, and a few of the most proninent of the native trees. The circumference of the trees has been ascertained four feet from the base, unless otherwise stated. The heights of all the trees has been estimated, and as this is a matter of judgment, without correct measurement, these heights are to be taken as approximately correct.

Ginkyo biloba Linn., the Maidenhair Tree, has been planted liberally throughout the city. The largest individual grows at No. 455 Lake Avenue. This is the old home of the late James Whitney. The circumference is 8.1 feet, and the height is 60 feet. Judging by its appearance, it might have been planted sixty years since. On the Ellwanger \& Barry grounds near the office, on Mt. Hope Avenue, there is a Maidenhair Tree with a circumference at three feet above the base of 6.5 feet, and the height is 55 feet. On what used to be the nursery grounds of the late T. B. Yale \& Son at the Winton Road near the canal bridge a Maidenhair Tree with a girth of 5.2 feet, and a height of 65 feet, shows a greater height than the other two on account of proximity, perhaps, to other trees. The Maidenhair Tree has not been found in a wild state but has been planted extensively in Japan and China for hundreds of years.

Pinus crucelsa Wall, the Bhotan Pine from the Himalayas, grows on the grounds of Mrs. Gilman Perkins, No. 421 East Avenue. This is a handsome species of white pine. The drooping leaves are six to eight inches long. It is 4.2 feet in circumference and 40 feet high, and is the largest individual in Rochester and vicinity.

Pinus ponderosa Dougl. the Bull Pine, native from British Columbia to Mexico, Nebraska and Texas, attains considerable size in this city. In the Ellwanger \& Barry nursery grounds, on MIt. Hope Avenue near the office there are two trees which measure respectively in circumference 6.9 and 5.8 feet: the larger is 65 feet and the smaller 60 feet in height. At No. 455 Lake Avenue a healthy individual of Pinus ponderosa measures 6.5 feet in circumference and is 55 feet tall.

Abics Nordmaniana Spach. from the Black sea regions is one of the noblest of the firs and it does remarkably well in Rochester. One of the best examples grows on the grounds of the Ellwanger \& 
Barry vineyard, Highland Avenue at the bottom of the south slope. It measures 4.9 feet in circumference, and is 75 feet in height. is far as can be ascertained it was planted with a number of other trces by the late George Ellwanger about sixty years ago.

Abies Picea Lindl. (A. pectinata DC.) the Silver Fir from the mountains of central and southern Europe, is a fir with a somewhat tender reputation. I fine individual grows on the east side of the Winton Road near the canal bridge, and south of the bridge. The circumference is 6.5 feet, and the height is 75 feet. The adjoining land where this tree stands was at one time an important nursery owned by T. B. Yale \& Son. It has been abandoned for many years and is now built 11 . This fir and a number of other important trees were planted by T. B. Yale \& Son about 1858 to 1860 as nearly as can be ascertained.

Sequoia Vellingtonia Seem., the famous Big Tree of California, was introduced by Ellwanger $\&$ Barry from California in 1864 . The seed came across the continent by pony express in a snuff box Thousands of seedlings were raised by Ellwanger \& Barry. and mostly sold in Europe. A group of five trees, from these seedlings. now stands near the office on Mt. Hope Nrenue. They vary considerably in size. The largest is 7.9 feet in circumference, and the height is 55 feet. What is probably one of the same group of seedlings stands on the old T. B. Yale \& Son nursery grounds on the Winton Road, but it shows signs of failing health. It is 6.5 feet in circumference, and 50 feet in height.

It is surprising to see on the old T. B. Yale \& Son nursery grounds a healthy individual of Libocedrus decurrens Torr., the Incense Cedar of the Pacific Coast. It is 2.5 feet in circumference. and is 35 feet tall. It is the only individual of any considerable size in Rochester and ricinity.

Chamaecyaris Law'soniana. T'arl., commonly known as Lawson': Cypress, is represented by a good healthy individual on the grounds of the Ellwanger \& Barry vineyard, at the botton of the south slope of the hill. It shows a peculiarly swollen base. The circumference is 4.9 feet and the height 40 feet. Is far as can be ascertained this is the only individual growing in Rochester and vicinity. with the 
exception of a few small plants growing in the conifer collection in the public parks. It is a matter of much surprise for many horticulturists to see this beautiful tree doing so well so far north. It is native from Oregon to California.

Juglans regia Linn., the Persian Walnut, commonly known under the name of English Walnut, has been considerably planted in the city and vicinity, and it bears crops of nuts quite freely. The largest individual tree in Rochester and vicinity grows in the village of Greece, on the Ridge Road, and on the side of the road. The circumference is 7.6 feet, and the height 45 feet. In interesting hybrid walnut grows at No. 1210 Culver Road, at the home of Miss Mary A. Booth. Her father, the late Dr. C. M. Booth, procured a nut from a Persian Walnut tree, growing at that time at the east end of Garson Avenue, and planted it at the rear of his house, about forty years ago. When this tree began to bear nuts it was observed they differed from the parent considerably. It was further noticed that the leaves, buds and bark of the tree were intermediate between the Butternut and English Walnut, and it consepuently proved to be a hybrid between the two. This was explained by the proxinity of a Butternut to the Persian Walnut from which Dr. Booth procured the nut. By a mere accident Dr. Booth happened to take the nut in which the pistil of the flower had been cross pollinated by the Butternut. The girth is 8.5 feet, the height 50 feet, and the spread of branches 75 feet. In orchard of Persian Wahnuts, consisting of about eight acres, has been established on the farm of $L$. S. Thompson, East Aron, and was planted thirty-one years since. This orchard has received considerable attention from the Bureau of Plant Industry, Washington, D. C.

Populus nigra variety betulifolia Torr. is a poplar of much interest. Nichanx found this poplar growing on the banks of the Hudson River and believing it to be a native Anerican poplar, gave it the name of Populus Hudsonica. Pursh again found it growing in 1814 somewhere on the shores of Lake Ontario, and named it Populus betulifolia. The date of its introduction from Enrope is anknown, but it is known to be a form of Populus nigra Linn. It does not seem to have perpetuated itself to any extent in this country, and the large individual in front of the Rochester Trade School at Ex- 
position Park is the only one known in Rochester and vicinity. It is a large well shaped individual, and has a girth of 9.4 feet and is 80 feet in height.

Qucrcus corris Linn, the Turkey Oak, is represented by a good sized individual on the east side of the Rochester Trade School and on the opposite side of the road at Exposition Park. It is the largest specimen in the city or vicinity. The circumference is 5 feet, and the height 40 feet. It is a native of Southeast Europe and West Asia. An interesting hybrid oak grows in Maplewood Park on Maplewood Avenue on the west side of the road and a short distance from Driving Park Avenue. It is a cross between Quercus alba Linn. and Quercus platanoides Sudw. The girth is 10.6 feet, and the height 70 feet. There are many splendid examples of the native oaks in the vicinity of Rochester, but there does not seem to be any sufficiently notable to indicate in this paper.

The European elms are well represented in the city of Rochester, where they have been extensively planted. On what used to be the estate of the late Samuel Wilder at the corner of East Avenue and Oxford Street, an immense individual of Ulmus campestris Smith, is in perfect health. This is the common elm of the roadsides in England, and is known as the English Elm. Its circumference is 14.3 feet, and the height by actual measurement is 101.72 feet. This tree was planted in 1850. Another good sized English Elm stands at No. 219 Alexander Street. The girth is 9.9 feet, and the height is 75 feet. Ulmus Hollandica variety i'egeta Rehdr., always known under the name of Huntington Elm, has been planted to some extent in the city. There are four good examples at the southeast corner of Goodman Street and Highland Avenue. Their girths are respectively $9.1,8.1,7.1$ and 7.1 feet. Two of the tallest are 80 feet in height. The Huntington Elm was first known at Huntington, England, in the middle of the 1Sth century. It is believed to be a hybrid between Ulmus glabra Huds. and Ulmus nitens Monch. Ulmus nitens Monch. sometimes known nnder the name of the Smooth Elm, is represented by a good individual at the east end of Avenue, $B$ about one hundred feet from the bank of the river, and on the south side of the Avenue. The girth is 7.2 feet, and the height 60 feet. Ulmus nitens is a common tree in the south of Eng- 
land and ranges from Central Europe to northeastern Asia. L'lmus Hollandica variety superba Rehdr. is a very graceful elm, and a very large example grows on the edge of the lawn in front of the Ellwanger \& Barry office on Mt. Hope Avenue. The circumference is 18.35 feet, and the height is 70 feet. It is said to have been! planted not over sixty years since. This is an extraordinary girth for a tree to attain in that time. At five feet from the ground it breaks into seven large boles, and has an enormous spread.

.There are numerous splendid examples of the American Elm, L lmus Amcricana Linn., in the vicinity of Rochester, and throughout the Genesee Valley. We will call attention to four individuals that are somewhat notable. In the grove in Cienesee Valley Park there is a very large American Elm with a wide spreading head, and in perfect health. The circumference is 16.8 feet, and the height is perhaps 100 feet. A good example of the vase form of the American Elm grows on the Latta Road about one mile west of Charlotte. The girth is $\mathbf{1 2 . 3}$ feet, and the height is 90 feet. A fine individual of the umbrella type of American Elm grows on the state highway about two miles east of the village of Avon. The circumference is 16.2 feet, and the estimated height is 110 feet. On the farm of Mr. W. G. Markham, two miles north of Avon there is now the lingering remnant of the "Markham Elm". This was a landmark in its day. All that remains of the tree is a large limb from the north side of the base and this is supported by a stout brace. This elm was first seen and attracted the attention in 1764 of Willians Markham who was a soldier in the colonial army and the great grandfather of the present William G. Markham. It was at that time a tree of extraordinary size. It is stated that during this known period of its history in four Markham generations no perceptible change was obsenved in its size. In the spring of 1893 the north side of the tree was blown down. Mr. Markham had this sawed across, and he counted three hundred and seventy-five rings. From the portion beyond which he counted, there was a large decayed area towards the center of the tree which he estimated proportionately, and he felt confident this elm had lived about six hundred years. The trunk was 45 feet in circumference three feet above the base, and at noon the shade of the branches extended over one acre. From 
all reliable accounts this tree was a most phenomenal ehm. It is said to have been of a distinctly pendulous form, with the branches drooping like a Babylonian Willow.

Torylon pomiferm Raf., the Osage Orange, which before the advent of wire fences, was an extremely poptular hedge plant, is a native of Kansas and Texas. It is quite hardy as far north as Massachusetts. An individual grows at the corner of Merchants Road and Culver Road, on the south side, and this appears to be the only tree of any size in the city and vicinity. The circumference is 7 feet, and the height 45 feet.

Magnolia acuminata Linn., the Cucumber Tree, grows native from Western New York to Alabama. It is found growing in a witcl state in the town of Parma, at Fishers, Ontario comnty, and at Portage Falls, on the Genesee River. At No. 455 Lake Avenue, a good individual stands, of which the girth is 6.6 feet, and the height 55 feet. On the grounds of H. B. Graves, No. $34+$ West Aventue there is a well developed cucumber Tree with a circumference of 6.2 feet and a height of 55 feet. A number of interesting trees were planted at the home now owned by H. B. Graves, and adjoining lots, by the late Captain Giles Kitts, between forty to fifty years since, as nearly as can be ascertained, including the magnolia referred to. Near the Ellwanger \& Barry office on Mt. Hope Avente there is a healthy individual of Magnolia macrophylla Michx. the Large-leaved Cucumber Tree. It the base of the stem the girth is four feet, and the height is 25 feet. This magnolia is mostly confined to the southern states in a native condition. The Chinese species and hybrid magnolias are abundantly planted throughout the city. The most notable example is the line of Chinese hybrid Magnolias along the center line of Oxford Street, south of Park Arenue. The ollest of these magnolias were planted over forty years since, by the late II. E. Hooker, who had an important nursery business on these lands at this time. The hybrid known under the name of speciosa was the one mostly planted. At the south end, additional plantings have been made since that time. These Magnolias attract the attention of many horticulturists who visit the city.

There are good examples of Liriodendron tulipifora Linn., the Tulip Tree, around the city. Some remarkably good individuals are 
found growing in Livingston Park. The largest grows at No. 5 Livingston Park. The girth is 8.3 feet, and the height is 80 feet.

Asimina triloba Adans, the Papaw, is a rare native shrub or small tree. The only known station in the vicinity of Rochester where it grows wild is on the Pudlong farm in the town of (ireece north of the Ridge Road. There is a thick colony of arborescent shrubs, which annually bear quantities of fruit. There is a similar native colony of the Papaw growing near lirockport.

A great deal of work has been done by members of the Park Department, and the Botanical Section of the Academy of Science during the past seventeen years in studying and investigating the genus Crataegus (American Hawthorn) in the vicinity of Rochester. Western New York and elsewhere, in collaboration with Dr. C. S. Sargent, the Director of the Arnold Arboretum, Harvard University Many new species were discovered. One of the most interesting of the new arborescent species was named after the late George Enwanger: Cratacgus Elladangcriana Sargent. The type plant stands at the west end of the grass walk in the Ellwanger \& Barry Nurseries on MIt. Hope Avenue. Mr. Ellwanger said a few years before his death that he remembered this hawthom very well fifty years ago, and he did not observe any perceptible increase in its size during that time. If no increase was noticed in this hawthorn in a period extending over sixty years, it surely must be of considerable age. and must have started on its life history long before it was seen by a white man. The circumference is 3.7 feet and the height 25 feet.

Gymnocladus Canadensis K. Koch., the Kentucky Coffee Tree. has been planted to some extent in the city. A well balanced tree grows on the grounds of H. B. Graves with a girth of $t$ feet, and a height of 40 feet. At the comer of Bay Street and Culver Road on the grounds of the old McGonegal home there is a Kentucky Coffee Tree with a remarkably wide spreading head. The girth is 4.6 feet, and the height 38 feet. A large Kentucky Coffee Tree grows at No. $17+$ South Coodman Street in front of the house. The circumference is 5.5 feet, and the height 50 feet. Another large Kentucliy Coffee Tree grows on the grounds of the Homeopathic Hospital on Alexander Street, the girth is 5.5 feet, and the height 55.8 feet. 
Sophora Japonica Linn., the Japanese Pagoda Tree, is a native of China, and is planted considerably in this country. A tree of considerable size grows inside the fence at No. 88 University Avenue. The circumference is 7.4 feet, and the height 45 feet.

Cladrastis lutea K. Koch., the Yellow Wood, is a native of Kentucky, Tennessee, Alabana, and North Carolina. It has been planted sparingly around the city. The largest individual grows on the grounds of Ellwanger \& Barry near the office. It branches at the base into five large boles, and the largest bole measures 6.5 feet in girth. It is 60 feet in height.

Acer campestre Linn., the English Field Maple, is not a rare tree in Rochester. Perhaps the largest individual grows at No. 360 IVest Avenue and is one of the trees planted by the late Captain Giles Kitts. The branches spread from the ground and it perhaps has a spread of forty feet. The circumference was not ascertained but it may be 9 feet in circumference at the base; the height is forty feet. Acer cappadocicum Gled. (Acer lactum C. A. Mey) a very beautiful maple native from the Orient to the Himalayas, is represented by a fine healthy individual in front of the home of $\mathrm{A}$. M. Lindsay, No. 973 East Arenue. At three feet from the base it measures 7.2 feet. At this point it branches into a wide spreading head. It is $\mathbf{5 0 . 3 6}$ feet in height by actual measurement. This seems to be the only tree of any considerable size in the city and ricinity. Acer opalus Mill. (Acer Italum Lauth.) is native from the Orient to the Hinalayas. There is a good sized individual growing on Mt. Hope Avenue on the land added to Highland Park, on what used to be the Narner estate. This tree is about two hundred feet northeast of the stone cottage. The circumference is $6.2 \mathrm{feet}$, the height is 35 feet. This is the only known example of this species in the city of Rochester. Acer macrophyllum Pursh, the Large-leaved Maple $\mathrm{f}_{1} \mathrm{om}$ Oregon and adjoining regions, is unquestionably a tender tree in the north. A splendid individual with a wide spreading head grew on the old nursery grounds of T. B. Yale \& Son on the Winton Road, and was one of the group of interesting trees planted by this firm previously alluded to. Most unfortunately it was cut down three or four years since to make room for a dwelling house. No measurements were ever taken of this maple, but it probably was "; 
feet in circumference and had a height of at least 45 feet. This perhaps was the only example of the Large-leaved Maple in Western New York of any size. The only large individual the writer has seen in the northeastern United States, is on the estate of Paul Dana, Glen Cove, Long Island.

Acsculus turbinata Blume., a handsome Horse-Chestnut from North China and Japan, is represented by a healthy individual in the Ellwanger \& Barry nurseries, at the east end of the grass walk which runs directly east from the office on Mt. Hope Avenue towards South Avenue. This is said to be the largest tree of this species known in cultivation in this country. The circumference is 5.5 feet two feet above the base and the height 35 feet. As an ornamental tree this species is handsomer than Aesculus hippocastanum Linn. in its foliage. There is an interesting collection of trees of the hybrids and varieties of the Pavia section of Aesculus adjacent to, and east of Acsculus turbinata. Perhaps no better can be seen in this country.

Tilia petiolaris DC., usually known as the Weeping Linden is a singularly handsome tree. A number of trees have been planted through the city. The largest appears to be at No. 7 Livingston Park. The circumference is 8.3 feet, the height is 60 feet. It is believed to have been planted over fifty years. This Linden is said to have been first observed on the streets of Odessa, Russia, and all the trees in cultivation are said to have originated from this tree. All the trees in cultivation are budded or grafted. The writer at one time sowed a large quantity of the seeds of this linden and out of several thousand seeds only a few geminated. These seedlings. showed great diversity, and none of them was the same as the parent. This seems to prove it to be a hybrid.

There are a few trees of Paulocinia imperialis Sieb. \& Zucc. in the city. What seems to be the best individual grows at the home of John M. Thayer, No. 66 James Street. It was planted twentyseven years ago. The girth is 6.7 feet, and the height by actual measurement 55 feet. It is a native of China and possibly of Japan.

Catalpa speciosa Engelm., the Western Catalpa, has become. noted of late years as a timber tree, useful for different purposes. It has been planted considerably in the city and vicinity. It does not 
a)pear to have been much planted fifty or sixty years ago. There are two large trees in front of the home of Mrs. Charles T. Depuy, No. 1075 East Avenue. The girth of the larger is 8.3 feet and the smaller 7.6 feet. The height by actual measurement is $6+$ feet. A well balanced Western Catalpa stands on Highland Avenue in front of the Ellwanger \& Parry vineyard, and is one of the numerous trees planted there by the late George Ellwanger at least sixty years since. The circumference is 8.1 feet and the height is 60 feet.

\section{STATistics.}

There have been added to our list since 1910, the following:

Species and varieties native to the Monroe Flora, 121

Species and varieties introduced to the Monroe Flora, 56

Total number of species and varieties,

New localities are given for 132 species and varieties noted as rare or scarce in the lists of 1896 and 1910.

The total number of species and varieties reported in the I'lants of Monroe County and Adjacent Territory, including the lists of 1896, 1910 and the present one is 1761.

\section{The Catalogue.}

\section{EXPLANATION OF THE PLAN.}

Aulhorities.-In arrangement and nomenclature this list follows the seventh edition of (iray's Manual of Botany; except for the Crataegus, in which Dr. Charles S. Sargent, Director of the Arnold Arboretum, is accepted as authority.

Typography and Reference Marks._Each species, variety or marked form regarded as an established member of our fiora is given a catalogue number. Those without number are not considered as fully established.

Heavy-faced type indicates species believed to be indigenous. Names of introduced species are printed in capitals, as are also the common or popular names.

The name of a cliscoverer of a plant new to our district, or of a new locality for a rare or scarce plant, is given in Italics. 
In the present list the genera are given the same number as in the previous lists. New genera are inserted in their proper order, and, to prevent confusion, are lettered, as $34 \mathrm{a}$, etc. Where new stations are given for rare or scarce plants, the number given in the previous lists is retained.

The list of 1910 closed with the number 1584. All numbers beyond that in this Second Supplementary List denote new species and varieties.

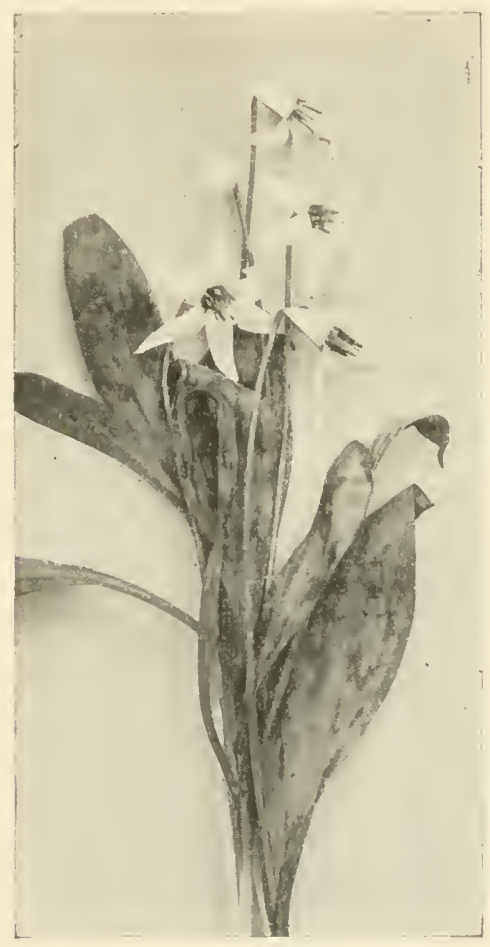




\section{PTERIDOPHYTA. \\ POLYPODIACEA.}

500. PHEGOPTERIS Fee. BEECH FERN.

1327. P. polypodioides Fee.

Brigg's Gully, Reynold's Gulf, Hemlock Lake, Honeoye Lake, M. S. Baxter and J. Laird.

499. CAMPTOSORUS Link.

1326. (. rlizopliyllus Link. WaLking FERN.

Five Corners, Rush, M. S. Baxter; Penfield, IV. Strecter, M. S. Baxter.

501. ASPIDIUMI Swartz.

1585. A. marginale $x$ goldianum Dowell. (comb. nov.)

Perinton, M. S. Baxter. A single plant.

1335. A. Boottii Tuckerm.

Sullivans, E. P. Killip.

503. ONOCLEA L.

1586. (). sensibilis L. var. obtusilobata (Schkuhr.) Torr.

Moist pastures, Greece, D. M. White.

LYCOPODIACEA.

508. LYCOPODIU, L. Ceub Moss.

1587. L. ammotinum L.

Gulick, J. Laird.

SELAGINELLACEÆ.

509. SELAGINELLA Beatv.

1584. S. apus (L) Spring.

Morganville, Genesee Co., M. S. Baxter.

SPERMATOPHYTA.

PINACEE.

488. ABIES Link.

1302. A. balsamea Mill. BALsam Fir.

Gulick, Ontario Co., M. S. Barter, J. Laird. Common.

NAJADACEÆ.

431. NAJAS L.

1588. I. Mnarina L.

Held's Cove, Irondequoit Bay, E. P. Killip. 
ALISMACEA.

436. SAGITTARIA I. ARROW-HEAD.

1589. S. arifolia Nutt.

Held's Cove, Irondequoit Bay, 1I. S. Baxter.

GRAMINEA.

44.) PASPALU. L.

1590. I’. Mnblenbergii Nash.

Bushnells Basin, Fishers and Victor, M. S. Batter. Occasional.

43. P.NICLN L.

1591. P. horeale Nash.

Irondequoit, .1. S. Ba.ter. Scarce.

1592. P. spretum Schultes.

Irondequoit, .1I. S. Batter. Rare.

1593. I'. Limdleimeri Nash.

Bergen swamp, Dr. C. H. Peck.

1594. P. implicatum Seribn.

Irondequoit, M. S. Barter; Mendon, E. P. Killip. Scarce.

1595. P. Acribnerianmm Nash.

Irondequoit, . I. S. Barter; Mendon, E. P. Killip. Scarce.

1596. P. Boscii Poir.

Canandaigua, Irs. E. P. Gardner.

44. SETARIA Beauv.

1207. S. italica (L.) Beauv.

Along railroad, Golah, E. P. Killip.

1597. S. virescells.

Mendon, E. P. Killip.

450. PHALARIS I. C.NARY GRass.

1215. P'. arundinacea $L$.

Adams Basin, E. P. Killip.

451. ANTHOXANTHUM L. SIVEET VERNAL Grass.

1217. A. ODORATUM I.

Bog near Round Pond, Manitou, E. P. Killip.

4.5:. HIEROCHLOE R. Br. HoLy GRASS.

1218. H. odorata Walıl. [H. borealis R. \& S.]

Sullivans, .1. S. Barter; Mendon, H. E. Hoodams \& Wr. A. Mattheres. Local.

4.53a. STIPA L. Feather Grass.

1598. S. comata Trin. \& Rup.

Cobbs Hill Reservoir, H. S. Ba.rter. 
45̋̈b. ARISTIDA L.

1599. A. oligantha Michx.

Along Penn. R. R., near Avon, M. S. Barter.

45. MLHLENBERGI.A Schreb.

1600. I. foliosa Trin.

Railroad tracks, Charlotte Dock, MI. S. Burter.

1224. I. racemosa (Michx.) BSP. [H. glomerata Trin.]

WVoolstons swamp, M. S. Ba.rter.

459. SPOROBOLUS R. Br. DROP-SEED.

1234. S. cryptaudrus Gray.

Forest Lawn, John Dunbar.

46. HOLCLS L.

1244. H. lanates L. Velvet Grass.

Meadows, East Avente, Rochester, C. Vollertscn.

470. BOUTELOt'A Lag. Grama Grass.

1601. B. oligostachya (Nutt.) Torr.

Cobbs Hill Reservoir, Florcnce Bcckith.

4\%. PHRAGMITES Trin. ReED.

1253. P. communis Trin.

Round Pond, Manitou, E. P. Killip.

472a. TRIDENS R. \& S.

1602. 'T. flavus Hitch.

Bushnells Basin, M. S. Barter: Atlantic Ave. Dugway, G. H. Chadwick.

474. ERAGROSTIS Beaur.

1258. E. Purshii Schrad.

Waste lots, Rochester, D. M. Whitc.

4isa. CYNOSLRL'S L. Dog's-TaIl Grass.

1603. C. cristatus L.

Lawns, East Ave., C. V'ollertsen. Apparently well established.

476. POA L. MEADOW GRASS.

1267. P. debilis Torr.

Mendon, M. S. Barter.

47. GLYCERIA R. Br. MANNa Grass.

1604. (i. canadensis Trin.

Bushnells Basin, M. S. Barter. Rare.

1271. G. pallida Trin.

Irondequoit, M. S. Barter. 
i:x. FESTLCA L. Frescue Griss.

1605. F. EL.ITIOR ARUNDINACE. Celak.

Wet meadow, Brighton, John I)unbur, M. S. Barter.

(:9. BROMLS L.

1286. B. TECTORUM L.

Fields, East Rochester, E. P. Killip.

1280. B. lialmii Gray

Sullivans, E. P. Killip.

[X:. HORDELTM L. BARIEY.

1292. H. inbatum L

Pittsford, F. S. Boughton; N. Y. C. R. R. tracks, Penfield, M. S.

Baster; Cobbs Hill Reservoir, Florence Beckaith; Braddocks Bay, E. P. Killip.

43:. CIPERT'S L.

1606. C. Engelmanni Stend.

Bushnells Basin, M. S. Batter. Rare.

134. ELEOCHARIS R. Br. SPIKE RUSH.

1061. E. rostellata Torr.

Sullivans, M. S. Barter; Mendon, E. P. Killip.

435. SCIRPL'S L. BULRT'SH.

1607. S. planiolius Muh1.

Sullivans, H. S. Baxter. Rare.

1067. S. caespitosus L.

Sullivans, .1\%. S. Barter.

1608. S. occidentalis Chase

Canandaigua, Miss E. C. Irebster: Maniton, E. P. Killip.

1609. S. atrociuctus Fernald.

Adams Basin, E. P. Killip.

436. ERIOPHORLM L. COTTON GRASS.

1610. E. tenelhm Nutt.

Mud Pond, Wayne Co., E. P. Killip.

439. SCLERIA Berg.

1087. S. triglomerata Michx.

Mud Pond, Wayne Co., E. P. Killip.

440. CAREX L. SEDGE.

1611. C. atlantica Bailey.

Bog near Round Pond, Manitou, E. P. Killip.

1612. C. stellulata Geed. var. aneustata Carey.

Mendon, M. S. Ba.rter. Scarce. 
1613. C. brumescens Poir.

Sullivans, M. S. Ba.rter. Rare.

1180. C. trisperma Dewey.

Manitou, E. P. Killip.

1614. C. vilpinoidea Mich. x comosa Boott.

Mendon Ponds, M. S. Baxter. One plant.

1615. C. setacea Dewey var. ambigua (Barratt) Fernald Adams Basin, E. P. Killip.

1616. ('. pallexeris: L.

Woolstons, Penfield, E. P. Killip.

1617. C. Iaxiflora Lam. var. Manda (Dewey) Boott.

Mendon, E. P. Killip.

1618. C. grisea Wahl. var. Rigida Bailey.

Sullivans, M. S. Barter.

1108. C. lanugimosa Michx. [C. filiformis L. var. latifolia Boeckl.] Woolstons, Manitou, Mud Pond, E. P. Killip.

1619. C. squarrosa L.

Golah, C. Vollertsen.

1566. C. Scluweinitzii Dewey.

Sandbar near Forest Lawn, I. Dering \& M. S. Barter.

1098. C. 'Tuckermani Dewey.

Penfield, $M$. S. Batrter.

1620. C. Lersia.

Egypt, Mud Pond, E. P. Killip.

1621. C. dispermia.

Bergen swamp, I. P. Killip.

\section{PONTEDERIACEÆ.}

41\%. HeterantherA R. \& P. Med Plantan.

993. H. dubia (Jacq.) MacM. [H.gruminca Vahl.]

Mendon, $W$. A. Matthere's.

\section{LILIACEE.}

410. ZYGADENUS Michx.

991. Z. chloranthus Richards. [Z. clegons Pursh.]

Sullivans, Miss A. B. Suydam.

409. VERATRLM L.

990. V. viride Ait.

Perry, Florence Beckicith. 
400. CLINTONIA Raf.

974. C. borealis Raf.

Sullivans, $H^{r}$. H. Bailey \& Dr. $H^{T}$. A. Hindell; Gulick Swamp, Baxter \& Laird.

399. DISPORUII Salisl).

973. I). launginosım Benth. \& Hook.

Lux woods, Pittsford, F. S. Boughton; Mendon, $I^{\prime}$. A. Matthen's.

391. SMILLAX L. Green Briar.

1622. S. rotumdifolia L. var. QUADRANGULARIS Wood.

Native in Seneca Park, B. H. Slazin.

\section{ORCHIDACEA.}

386. HABENARIA Will.

941. H. dilatata Gray.

Mud Pond, Wayne Co., M. S. Baxter.

943. H. orbiculata Torr.

Honeoye Lake, $I I$. A. Mather's.

381. SERAPIAS L. (EPIPACTIS Haller.)

931. S. Helleborine L.

Golah. Common. East Shore, Irondequoit Bay, Killip \& Wl oodams; Rattlesnake Point, D. M. White; Hamlin, Miss Beckavith.

379. SPIRANTHES Rich. LAdies' Tresses.

925. S. Iucida Ames. [S. latifolia Torr.]

Egypt, Dr. L. R. Cormman; Greece, Miss A. B. Suydam.

926. S. Romanzoffana Cham.

Sullivans, MI. S. Baxter.

3\%. CORALLORRHIZA R. Br. CORAL RoOT.

920. C. trifida Chatelain [C. innata R. Br.]

Gulick, J. Laird.

921. C. odontorhiza Nutt.

Bushnells Basin, Mrs. Helen Rockerell: Perinton, M. S. Baxter; Springwater, Livingston Co., Baxter \& Laird; Woolstons, M. IVoodams.

373. LIPARIS Rich. TMAYBLADE.

915. L. liliifolia Rich.

Bullhead Pond, Perinton, Miss A. B. Suydam.

916. I. Loeselii (L). Richard.

Barrett farm, Pittsford, E. P. Killip.

3\%. APLECTRUM Torr. PLTTY-Root.

919. A. lyyemale Nutt.

Riga, Florence Beckrith. 
SALICACEAE.

366. SALIX L. WILLOW.

886. S. serissima Fern.

Spencerport, 11. S. Barter.

1623. S. cordata var. Mrricomes (Muhl) Carey.

Shore of Lake Ontario near Braddlocks Point, E. P. Killip.

\section{JUGLANDACE.E.}

356. CARYA Nutt. HІскокY.

1624. C. orata var. firininifolia Sarg.

Type, Conesus and Mount Morris, John Durbar; Rochester and Nacedon, B. H. Slazin. Trees and Shrubs, Vol. 2, p. 207.

1625. C. ovata var. Nuttallii Sarg.

Canandaigua, B. H. Slarin. Trees and Shrubs, Vol. 2, p. 207.

1626. C. Laneyi Sarg. (A hybrid of ('. ovatax 1 . eorliformis).

Type, Riverside Cemetery, H. B. Broz'n, John Dunbar, C. S. Sargent. Rare. Trees and Shrubs, Vol. 2, p. 196.

1627. (. porcina var, acuta Sarg.

Type, Seneca Park, B. H. Slarin: Mendon, C. C. Lancy, R. E. Horsey. Scarce. Trees and Shrubs, Vol. 2, p. 200.

1628. (". megatarpa Sarg.

Type, Seneca Park, B. H. Slurin; Highland Park, R. E. Horsey. Rare. Trees and Slirubs, Vol. 2. p. 201.

1629. (. walis Sarg.

Mount Morris and Rochester, John Dunbar and R. E. Horsey. Rare. Trees and Shrubs, Vol. 2, p. 207.

1630. ('. ovalis varobeordata Sarg.

Maplewood Park, C. C. Lancy. Frequent. Trees and Shrubs, Vol. 2, p. 208.

1631. ('o oralis var, obovalis Sarg.

Rochester, John Dunbar. Scarce. Trees and Shrubs, Vol. 2, p. 209.

1632. Covalis var. odorata Sarg.

Rochester, John Dunbar; Conesus Lake, B. H. Slavin and R. E. Horsey. Common. Trees and Shrubs, Vol. 2, p. 207.

\section{BETULACEA}

359. ALNUS Hill. Alder.

865. A. rugosa Spreng. [A. serrulata Willd.]

Durand Park, Joln Dunbar, B. H. Slazin. Scarce. 
LRTICACEA.

315. TLMLS L. ETM.

837. I. racemosa Thomas. Corky Enar.

Bergen, M. S. Barter.

346. CELTIS L. II.ACKBERY.

8.38. Coccilentalis L.

Reed's Swamp, near Scottsville, M. S. Barter.

350. L'RTiCA L. Nettle.

1633. U. Chamaenryoldes Pursh.

Lawn, University Ave, Florence Beckaith.

\section{CHENOPODIACE.E.}

3?(6). KOCHII.A Roth.

1545. Ǩ. SCOPARIA Schrad.

Becoming common throughout the city.

32. CHENOPODILU L. PIGWEED.

1548. C. AMrRosiones L.

Sonth Clinton Street, C. Vollertsen; Lake Ave., F. Beckaith.

1546. C. Vtruiria L. [C. foetidum Lamk.]

South Avenue, M. S. Barter.

783. C. LRBICLN L.

Railroad weed, East Rochester, M. S. Bartir.

3:8. ATRIPIEY I.

1634. A. ROsEA L. Cobbs Hill Reservoir, Florence Beckuith.

AMARANTIJACEA.

326. AWARANTHLS [Tourn.] L.

781. 1. Hitoides Wats.

Wendt farm, Barnards, E. P. Killip.

\section{ILI.ECEERACEA.}

3\%51\%. SCLERANTHI'S L.

1543. S. ANxtes L.

Shore of Lake Ontario, Town of Hamlin, Florence Beckath.

33.5. ANYCHIA Michx. Forked ChICKWEed.

1635. 1. canadensis (L.) BSP.

Dry ravines, Naples, M. S. Barter; Seneca Point, Canandaigua Lake, Mrs. E. P. Gurdner; Scottsilile, Florence Beckwith. 


\section{CARYOPHYLLACEÆ.}

60. SPERGULA L. PEARLWORT.

130. S. ARIENSIS L.

Hamlin, Miss Beckzith: Barnards, E. P. Killip.

56. ARENARIA L. SANDWORT.

122. A. lateriflora L.

Sullivans, Mrs. L. R. Cormman.

55. LYCHNIS L.

119. L. Coronaria Desv. Mullein Pink.

Canandaigua, Mrs. E. P. Gardner.

1636. L. Flos-cuculi L. Ragged Robin.

Meadows, East Ave., C. Vollertscn.

1378. L. alba Mill. [L. vespertina Sibth.]

Cobbs Hill Reservoir, Miss Bcekwith.

54. SILENE L. Catchify.

1377. S. Dichotoma Ehrh.

Wheatland, near Scottsville, Florence Beckzith.

113. S. Latifolia Britton \& Rendle [S. cucubalus Weible.] Bladder CAMPION.

Becoming common.

116. S. Armeria L. Sweet W'illiam Catchily.

Vacant lots, Rochester, D. M. Whitc.

\section{RANUNCULACEÆ.}

6. RANLNCLLES L. BUTTERCUP.

13. R. delphinifolius Torr. [R. multifidus Pursh.]

Golah, M. S. Ba.ter, and M. IToodams.

15. R. Flammula L. var. reptans (L.) Mey.

Long Point, Sodus Bay, E. P. Killip.

8. Trollius t. Globeflower.

27. T. laxus Salisb.

Gulick Swamp, Barter \& Laird.

12. ACTAEA L. BANEBERRY.

1637. A. rubra (Ait) Willd. forma NegLecta Robinson, with white berries on long slender green pedicels.

Woolstons, E. P. Killip.

13. HYDRASTIS Ellis.

33. H. canadensis L. GOLDEN SEAL.

Allens Creek, Brighton, Lewis S. Gannett; Golah, M. S. Barter; Sullivans, F. Boughton. 
BERBERIDACEA:

20. JEFFERSONTA B. S. Barton. TWINIDAF.

40. J. diphylla Pers.

Culvert 79a, near Fishers, I. Laird; Riga, M. S. Barter; The Gulf, Genesee Co., Mrs. John Demnis: Mendon, Wr. A. Matther's.

\section{PAPAVERACE $\mathrm{E}$.}

3Xa. ARGEMONE L. PRICKLY POPPY.

1638. A. Mexicana L.

Vacant lot, C. Tollertsen.

\section{FLMARIACEA}

"9. ADLUMIIA Raf. Cimining Fumitor:

53. A. fungosa (Ait.) Greene. [A. cirrhosa Raf.]

Lake shore about one mile east of Deril's Nose, Florence Beckwith; one mile east of mouth of Sandy Creek, M. S. Barter; Mumford, Miss Nellie Hy'nes.

\section{CRUCIFERE.}

34b. LOBULARIA Desv.

1639. L. maritima (L.) Dest. sweet alyssum.

Cobbs Hill Reservoir, Florenee Bcckzeith; Highland Ave., E. P. Killip.

3.5. ALYSSLM L.

68. A. Alyssoides L. [A. calyeinum L.]

Charlotte, J. Laird.

4. thlaspi L. Penny Cress.

85. T. ARVENSE L.

Pittsford, F. Bonghton; Float Bridge, Mrs. Helen Rockwell; vacant lots, D. M. White.

45. LEPIDIL M [Tourn.] L.

89. L. Campestre (L.) R. Br.

West Bergen, E. P. Killip.

36. CAMELINA Crantz. False Flax.

69. C. SATINA Crantz.

City streets, C. Vollertsen.

1640. C. Microcarpa Andrz.

Canandaigua, Miss E. C. Webster.

36a. NESlia Desr. Ball Mustard.

1641. N. Panicclata Desi.

Greece, George Arnold. 
4. BRASSICA L. MUSTaRd.

1642. B. CAMPESTRIS L

Scottsville, Florence Beckwith.

42b. CONRINGIA Link. Hare's-EAr Mustard.

1366. C. oRtintalis Link.

West Shore railroad tracks, Pittsford, F. Boughton.

19e. AlLiARIA Adans, Garlic Mustard.

1643. 1. ofticinalis Andrz.

Highland Ave., Rochester, E. P. Killip.

41. SisyMBrIUM L. Hedge Mustard,

1364. S. altissincm L. Tumble Mustard.

Has become common throughout the city and ricinity.

81. S. Thaliantu (L.) J. Gay.

Vacant lots, Rochester, F. Bcckwith.

39. HESPERIS L. ROCKET.

78. H. MATRONALIS L.

Brighton, J. Laird.

3\%. RADICULA [Dill.] Hill. [NASTURTIUM R. Br.]

74. R. ayuatica (Eat.) Robinson. [Nasturtium lacustrc Gray.] Sodus Bay, E. P. Killip.

33. CARDAMINE [Tourn.] L.

62. C. pratensis $L$.

Mendon, IV. A. Matthezos.

34. ARABIS I.

1361. 1. Irummondi Gray. [A. confinis Wats.]

Canandaigua Lake, Mrs. E. P. Gardner.

64. L. hirsuta Scop.

Ravine at Buttermilk Falls, II. S. Barter.

SARRACENIACEA.

36. SARRACENIA L. Pitcher-Plaxt

50. S. purpurea L.

Rochester Junction; Sullivans, Botanical Section.

SAXIFRAGACEA.

12\%. MITELLA L. BISHOP'S CAP.

316. M. Huda L.

Sullivans, IIiss A. B. Suydam.

130. RIBES L.

320. R. rotumdifolinm Michx.

Bergen swamp, E. P. Killip. 
1644. R. triste Pall, var. Albinervum Fernald.

Bergen, M. S. Barter.

\section{ROSACE $\mathrm{E}$}

111. SPIRAEA L.

260. S. tomentosa L. HaRnHack.

Simpson's Woods, Killip \& Woodams, Mrs. John Donnis, Miss A. B. Suydam.

129. MALLTS S. F. Gray. Apple.

1645. M. glancescens Rehdr. (Described in Trees and Shrubs 2, 139.)

Type in Maplewood Park, Rochester, John Dumbar. Frequent.

1646. M. fragrans var. elongata Rehdr. (Trees and Shrubs 2, 229.)

Type at Chapinville, Ontario Co., John Dunbar and B. H. Slavin.

124. AMElanChier Medic. Juneberry. Shadeush.

1647. 1. humilis Wiegand (Described in Rhodora 14, 141.)

Frequent along banks of Genesee River and elsewhere, John Dunbar

1648. A. stolonifera Wiegand. (Rhodora 14, 141.)

Occasional, Mendon, M. S. Baxtcr.

123. CRATAEGt'S L. Hawthorn. White Thorn.

1649. C. eastmaniana Sarg. (N. Y. State Mus. Bul. 167, 141. 1912.)

Durand-Eastman Park, Henry T. Brozen.

1650. (. pausiaca Ashe (Trees and Shrubs 1, 105 t 5.3.)

Chapinville, John Dumbar.

1651. ('. hrownietta Sarg. (N. Y. State Mus. Bul. 167, 78, 1912.)

Common around Hemlock Lake, H. T. Brozen:

1652. C. obstipa Sarg. (N. Y. State Mus. Bul. 167, 80, 1912.)

Near Chapinville, B. H. Slazin.

1653. C. prominen: Sarg. (Ont. Nat. Sci. Bul. 4, 23, 1908.)

Hemlock Lake, H. T. Brown.

1654. C. latiflora Sarg. (N. Y. State Mus. Bu1. 167, 83, 1912.)

Richmond, Livingston Co., H. T. Brown.

1655. ('. scitula Sarg. (N. Y. State Mus. Bu1. 167, 84, 1912.)

Chapinville, B. H. Slazin.

1656. C. placina Sarg. (N. Y. State Mus. Bul. 122, 46, 1908.)

Belfast, M.S. Barter and $V$. Dering.

1657. C. pulchra Sarg. (N. Y. State Mus. Bu1. 122, 42, 1908.)

Chapinville, $B$. H. Slazin.

1658. ('. seclusa Sarg. (N. Y. State Mus. Bu1. 167, 89, 1912.)

Richmond, H. T. Broz'n. 
1659. ('. promissa Sarg. (N. Y. State Mus. Bul. 122, 30, 1908.) Hemlock Lake, H. T. Brown.

1660. ('. congestitlora Sarg. (N. Y. State Mus. Bul 122, 1H, 1908.) Castile and Belfast, Barter \& Dewing; Palmyra, B. H. Slavin.

1661. C. crula Sarg. (N. Y. State Mus. Bul. 122, 54, 1908.) Hemlock Lake, H. T. Brown.

1662. (. suavis Sary. (N. Y. State Mus. Bul. 122, 59, 1908.) Hemlock Lake, H. T. Broan.

1663. ('. conferta Sarg. (N. Y. State Mus. Bul, 122, 62, 1908.) Rochester, John Dunbar.

1664. ('. vivida Sarg. (Ont. Nat. Sci. Bul. 4, 47, 1908.) Chapinville, B. H. Slavin.

1665. (. dayana Sarg. (N. Y. State Mus. Bu1. 122, 66, 1908.) Hemlock Lake, H. T. Brown.

1666. (. perrara Sarg. (N. Y. State Mus. Bul. 167, 103, 1912.) Chapinville, B. H. Slazin; Honeoye Lake, H. T. Brou'n.

1667. ('. misella Sarg. (N. Y. State Mus. Bu1. 167, 115, 1912.) Belfast, Ba.ter \& Dewing.

1668. ('. spinifera Sarg. (N. Y. State Mus. Bul. 122, 118, 1908.) Canandaigua, B. H. Slavin; Hemlock Lake, H. T. Brou'n.

1470. C. structilis Ashe (N. Y. State Mus. Eul. 122, 77, 1908.) Chapinville, Rochester, Hemlock Lake, John Dunbur.

1669. C. truculenta Sarg. (N. Y. State Mus. Bul. 167, 118, 1912.) Belfast, Barter \& Dewing.

1670. (. Jalkwillii Sarg. (Ont. Nat. Sci. Bu1. +, 80, 1908.) Chapinville, B. H. Slavin.

1671. (. somnenbergensis Sarg. (N. Y. State Mus. Bul. 167, 120, 1912.) Canandaigua, B. H. Slavin.

118. POTENTILLA L. CixQUEFUIL.

279. P. paradoxa Nutt. [P. supina Gray.]

Long Pond, Braddocks Bay, Killip ơ Hoodams.

11.5. $G E L: U 1$ 1.

1672. (i. Havum Bick.

Canandaigua, Mrs. E. P. Gardner.

114. D.AI.IBARD.A Kalm.

269. H. repens L.

Gulick Swamp, Barter \& Laird. 
119. AGRI.MONI.A [Tourn.] ]..

1673. I. striata Michx.

Mendon, $I V$. A. Matthews.

LEGUMINOSE.

94a. ANTHYLLIS L.

1674. A. nulneraria L.

Cobbs Hill Reservoir, Miss .M. E. Macauley and . Miss I'. Beckwith.

96. TEPHROSIA Pers.

212. 'T. virginiana Pers.

Sullivans, .Urs. John Dinnis.

101. DES.HODIUM Desv.

230. J), marilandieum (L.) DC.

Greece, E. P. Killip.

102. LESPEDEZA Michx. Bush Clover,

235. L. capitata Michx.

Banks of Irondequoit Eay, also S. Goodman St., Rochester, E. P. Killip.

103. VICIA L. VETCH.

1675. V. villosA Roth.

Vacant lot near South Ave., Mrs. John Dennis.

OXALIDACEE.

7׳. OYALIS L. WWOD SOREL.

1384. O. Acetosella L.

Reynolds Gulf, Hemlock Lake, Barter \& Laird.

GERANIACEA:

i1). GERANIUU [Tourn.] L.

153. G. calolinianum $\mathrm{L}$.

Mendon, $W$. A. Mattherus.

\section{EUPHORBIACEN.}

343. ELPHORBIA L.

1676. E. glyptosperma Engelm.

Dry sand hills, Point Pleasant, Irondequoit, Killip \& Woodams.

830. E. corollata L.

Bushnells Basin, M. S. Barter. Rare.

CISTACEN.

49. LECHEA L.

93. L. villosa E11. [L. major Michx.]

Victor and Perinton, .1. S. Barter. Frequent 
94. L. intermedia Leg. [L. minor L.]

Victor and Perinton, M. S. Baxter. Frequent.

\section{VIOLACEA.}

51. hybanthuS Jacq. Grefin Violet.

109. H. concolor (Forster) Spreng. [Solca concolor Ging.] Powder Mills, F. Bonghton.

50. VIOLA L.

1677. V. nephrophylla Greene ( $V$. vagula Greene.)

West Bergen, Dr. H. D. Housc. Occasional.

1678. V. latiuscula Greene.

Swamp road, Victor, $W$. A. Matthea's.

\section{V. incognita Brainerd.}

Sullivans, E. P. Killip.

101. V. rotundifolia Michx.

Palmers Glen, Rochester, F. Boughton; Densmore Creek, M. S. Ba.rter; Springwater, Livingston Co., Barter \& Laird.

\section{LYTHRACEX.}

138. LYTHRUM L

341. L. Salicaria L.

Palmers Glen, E. P. Killip.

\section{ONAGRACE王.}

141. EPILOBIUM L.

1679. E. HIRSUTUM L.

Reeds swamp, north of Scottsville, M. S. Baxter; Scottsville, Florchec Beckwith; Bergen, Killip \& I'oodams; Mendon, $I$. A. Matthew's.

1680. E. densum Raf.

Golah, E. P. Killip.

1483. E. åenocanlon Haussk.

Sullivans, E. P. Killip.

14:. OENOTHERA L. Evening Primiose.

1681. O. oakesiana Robins.

Canandaigua, Mrs. E. P. Gardner.

1682. (1. muricata L.

Canandaigua, Mrs. E. P. Gardner.

1683. (o. muricata var. CANescens Torr. \& Gray.

Canandaigua, Mrs. E. P. Gardner.

1684. 0. pallida Lindl. [Anogra albicaulis Britton.]

Cobbs Hill Reservoir, Florence Beckwith. 
349. 0. pumila L.

Coldwater, J. Laird. 143. GALRA L.

351. (4. biennis L.

Golah, E. P. Killip.

UMBELLIFER Æ.

164. SANICULA L

1685. S. canadensis $\mathrm{L}$.

Canandaigua Lake, Mrs. E. P. Gardner.

CORNACEE.

166. CORNUS L. DOGWOOD.

1686. C. Slavini Relider.

Type plant in Seneca Park, Rochester, B. H. Slavin.

ERICACEÆ.

239. CHIMAPHILA Pursh.

606. C. maculata Pursh.

Perinton, Miss A. P. Suydam.

211. PYROLA [Tourn.] $\mathrm{L}$.

1687. P. incarnata (Fisch.) Fernald. [P. uliginosa Torr.]

Mendon, $W$. A. Matthez's.

229. VACCINITTM L.

1688. V. pennsylvanicum Lam. var. Angustifolium (Ait.) Gray.

Rocky ledges, Leroy, M.S. Baxter.

1525. V. atrococeum (Gray) Heller.

Bushnells Basin, E. P. Killip.

PRIMULACEA.

21\%. ANAGALLIS [Tourn.] L. P'IMPERNEL.

1689. A. ARvensis L. var. CAerulea (Schreb.) Ledeb.

Canandaigua, Mrs. E. O. Cartzeright.

\section{GENTIANACEA.}

255. GENTIANA L.

642. G. puberula Michx.

Bushnells Basin, F. Boughton and Florence Beckwith. This station has since been destroyed.

25\%. BARTONIA Muhl.

646. B. virginiea (L.) BSP. [B. tenclla Muhl.]

Simpson's Woods, James Bishop. 


\section{ASCLEPIADACE E.}

253a. CYNANCHUM L.

1690. C. Vincetoxicum (L.) Pers.

Dry fields, Highland Ave., D. M. White.

\section{CONVOLVULACEA.}

?70. CONVOLVULVLS L. BINDWEED.

1691. C. sepium L. var. pubescens (Gray.) Fernald.

Canandaigua, Mrs. E. P. Gardner.

271. CUSCLTA L. DODdER.

1692. C. ерітнумum Murr.

Caledonia, Florence Beckwith.

\section{POLEMONIACEN.}

259a. POLEMONIUM L.

1693. P. reptans L.

Near Log Pond, Caledonia, C. Vollertsen and Florence Beckwith.

BORAGINACEE.

261. CYNOGLOSSUM (Tourn.) L.

654. ('. virginicum L. WILd Comfrey.

Springwater, Livingston Co., Mattheris \& White.

?6isa. ONOSMODIUM Michx.

1694. (I. hispidissimum Mack.

Dugan Creek, Livingston Co., M. S. Bu.rter.

\section{VERBENACER.}

301. VERBENA L.

1695. V. stricta Vent.

Irondequoit, Jame's Bishop; Pittsford, F. Boughton.

1537. V. bracteosa Michx.

Highland Park and Cobbs Hill Reservoir, Florence Beckwith.

\section{LABIAT E.}

30\%a. AJUGA L. BUGLE WEED.

1696. A. REPTANS L.

Canandaigua, Mrs. E. O. Cartwright.

303. TEUCRILM L.

1697. 'T. oceidentale Gray.

Canandaigua, Mrs. E. P. Gardner; Pittsford, F. Boughton. 
3:3. GAleEOPSIS L. Hemp Nettle.

1698. G. LadANUM L. var. LAtifolia Wallr.

Along West Shore railroad, Pittsford, F. Boushton.

32:. Lamilu I. Dead Nettle.

1699. L. PURPUREUM L.

IV. A. Matthers. Common.

324a. SAIVIA L.

1700. S. NUTANS L.

Caledonia, F. Beckwith. Adventive.

314. MONARDA L.

755. I. clinopodia L.

The Gulf, Mrs. John Dennis; Mendon, W. A. Matthea's.

31.5. BLEPHIIJA Raf.

1701. B. hirsuta (Pursh) Benth.

Buttermilk Falls, D. M. White.

308. PYCN INTHEMUM Michx.

1539. P. Hexuosum (Walt.) BSP. [P. linifolium Pursh.]

Mendon, W. A. Matthews; Forest Lawn, .Mrs. H. C. Pierce.

745. P. virginianum (L.) Durand \& Jackson [P. lanccolatum Pursh.]

Woolstons, Mrs. L. R. Cormman, E. P. Killip.

\section{SOLANACE E.}

27:. SOLANUM [Tourn.] L. Nightshade.

675. S. carolinense L.

Two miles south of Sodus, E. P. Killip.

27\%. HYOSCYAMUS L.

683. H. NIGER L. -

Waste places around Rochester, C. Vollertsin.

\section{SCROPHULARIACEE.}

?81. LTNARIA [Tourn.] Hill.

689. L. canadensis (L.) Dumont.

Golah, E. P. Killip.

1702. L. MINOR (L.) Desf.

North Bergen, Killip \& Woodams, 1913; Stanley, Bartor ơ Laird, 1914.

383. SCROPHULARIA L. FIGWORT.

1703. S. Jeporella Bick.

Dugan Creek, Caledonia, $M$. S. Ba.rter; east side Irondequoit Bay, D. M. White. 
285. PENTSTEMON Mitch.

695. P. laerigatus Solander.

WTest Shore railroad tracks, near Bergen, Killip \& IVoodams.

289. V'ERON/CA L. SPEEDWELl.

702. V. virginica $\mathrm{L}$.

West Rush, M. S. Barter: Scottsville, Florence Beckixith.

293. PEDIC CLARIS L.

720. P. lanceolata Mich:

Turk's Hill, Leacis S. Gannett.

\section{PLANTAGINACE玉.}

3\%5. PLANTAGO L. P'LANTAIX.

17(14. P. MEDIA L.

Canandaigua, Miss E. C. II cbster.

1541. P. aristata Michx. [P. patagonica var. aristata Gray.]

Woolston road, Perinton, M. S. Ba.rter.

1705. P. virginica $L$.

On dry hillsides, Sullivans, M. S. Barter. Rare.

\section{RUBIACE王.}

178. GALIL̈li L. Bedstraw.

421. G. pilosum Ait.

Pittsford, C. Vollertsen.

1706. G. Sylyaticum L.

Pittsford, E. P. Killip.

1707. G. labradoricum Wiegand.

Mud Pond, Wayne Co., E. P. Killip.

17. HOLSTONIA L.

413. H. caerulea L.

Gulick, Miss A. B. Suydam; Springwater, Livingston Co., Matthew's \& llhite.

\section{CAPRIFOLIACE $/$.}

170. TRIOSTELM L.

1708. T. aurantiacum Bick.

Canandaigua Lake, Mrs. E. P. Gardner.

\section{VALERIANACE.}

179. TALERIANA [Tourn.] L.

430. Y. uliginosa (T. \& G.) Rydb. [ $l^{\text {T}}$. sylitatica Man. ed. 6.] Swamp road, Victor, II. A. Matthez's. 
DIPSACACENE.

I81:2. K.IT TIA L.

1709. K. ARTENSIS (L.) T. Coulter.

Meadows, East Ave, Rochester, C. Vollcrtscn.

COMPOSITAE.

183. EIPATORITU [TOUI].] L.

1710. E. purpureum L. var. mateulatum (L.) Darl.

Swamps, Mendon, E. P. Killip.

1711. k. purpurem L. var. foliosum Fernald.

Swamps, Sullivans, II. S. Butrter.

1712. K. peroliatum L. var. Trtexcatum Gray,

Greece, E. P. Killip: Irondequoit, D. W. White.

18:a. GRINDEI.IA Willd.

1713. (A. squilrosal Dunal.

Cobbs Hill Reservoir, Florence Beckwith.

1714. O. squaroua Dunal. var. NLDA Gray.

Cobbs Hill Reservoir, Florcnce Bcckwith.

- 183H. CHRYSOTHAMUS Nutt.

1715. (. Juiniolia Greene.

Cobbs Hill Reservoir, M. S. Barter.

183e. GLTIERREZI.1 Lag.

1716. G. Narothrae Britton \& Rusby.

Cobbs Hill Reservoir, Florcnce Beckwith.

184. SOLIDAGO L.

1717. s. carsia L. var, axillakis (Pursh) Gray.

M. S. Barter. Frequent.

1718. S. adevia L. var. PANGeUlata Gray.

11. S. Baxtcr. Occasional.

1719. S. Hispida Muhl. Branched form. Greece, D. I. White.

1720. S. juncea Ait. var. scabrella (T. \& G.) Gray. M. S. Baxter. Occasional.

1721. S. uniligulata (DC.) Porter var. levipes Fernald (Rhodora 17, 7.) Bergen swamp, Dr. C. II. Pcck, 1880.

1722. S. aspera Ait.

II. S. Barter. Common.

184a. SIDERANTHUS Sweet.

1723. S. gracili: Rydb.

Cobbs Hill Reservoir, M. S. Barter, Florence Bickwith. 
186. ASTER L.

467. A. laevis $\mathrm{L}$.

A peculiar form of this species with elongated leaves and long narrow panicle, blooming in late October and November, has been found for several years in succession on the Pinnacle Hills by $C . H$. Vollertscn.

1724. 1. Schreberi Nees.

Seneca Park, B. H. Slazin. Occasional.

469. A. multillorus Ait.

Cobbs Hill Reservoir, Florcnce Bcckrith.

1725. A. longifolius Lam.

Greece, D. M. White.

1726. A. novi-Belgii L.

Canandaigua, Mrs. E. P. Gardncr.

1727. A. tardiflorus L.

Simpson's woods, Mrs. John Dennis.

186a. MACHAERANTHERA Nees.

1728. M. tanacetifolia Nees.

Cobbs Hill Reservoir, M. S. Ba.rter.

1729. I. pulverulenta Greene.

Cobbs Hili Reservoir, F. Bcckwith.

183. ANTENNARIA Gaertner. Everlasting.

1730. A. Parlinii Fernald var. arnoglossa Greene.

Ogden and Lime Rock, M. S. Ba.ter. Scarce.

1731. A. canalensis Greene.

Dry hills, M. S. Baxter. Common.

1732. A. fallax Greene.

M. S. Barter. Common.

1733. A. occidentalis Greene.

M.S. Ba.rter. Common.

1734. A. neodioica Greene.

Penfield, M. S. Baxter. Common.

1735. A. grandis (Fernald) House.

M. S. Baxter. Common.

1736. A. neglecta Greene.

Penfield, M.S. Barter. Occasional.

1737. A, petaloidea Fernald.

M. S. Barter. Common. 
190. G.V.APHAI.TL.II L.

1738. (:. purpureum L.

Sullivans, M. S. Baxtcr. Rare.

19?. POLYWNIA I.

496. P. canadensis $L$.

Caledonia, F. Beckaith; The Gulf, Botanical Section.

195. HELIOPSIS l'ers.

504. H. seabra Dunal.

Canandaigua, Mrs. E. P. Gardncr.

195a. GYHNOLOHIA H.B.K.

1739. (4. multillora B. \& H.

Cobbs Hill Reservoir, F. Bcckaith.

198. HELIANTHL'S L

1507. H. petiolaris Nutt.

Railroad weed, East Rochester, M. S. Bartcr; Cobbs Hill Reservoir, Florence Beckwith; The Gulf, Dr. L. R. Cornman.

201a. DYSSODIA Cav.

1740. I. papposa (Vent.) Hitchc.

Cobbs Hill Reservoir, M. S. Baxtcr.

203a. MATRICARIA L. WILD ChAMOMILE.

1741. M. CHAMOMILLA L.

Waste places around city, C. Vollcrtscn.

1742. M. SUAveolens Buch.

Canandaigua, Mrs. E. O. Cartzuright.

206. ARTEMISIA L.

529. A. caudata Michx.

Lake Shore, D. M. Whitc.

530. A. canadensis Michx.

Waste lot, Rochester, D. M. White.

1743. A. dracmeuloides Pursh.

Cobbs Hill Reservoir, F. Beckwith.

1744. A. gìuca Pall.

Cobbs Hill Reservoir, M. S. Burter.

1745. A. filifolia Torr.

Cobbs Hill Reservoir, F. Bcckwith.

1746. A. frigida Willd.

Cobbs Hill Reservoir, I. Beckaith.

532. A. biennis Willd.

Cobbs Hill Reservoir, M. S. Baxtcr; Highland Park, F. Bcckaith:

Exchange street, F. Boughton. 
1747. A. gnaplialoides Nutt.

Cobbs Hill Reservoir, F. Beckwith.

1748. A. trifida Nutt.

Cobbs Hill Reservoir, F. Beckwith.

1749. 1. carruthi Wood.

Cobbs Hill Reservoir, M. S. Baxter.

30!. SENECIO L.

1750. S. eremophilus Rich.

Cobbs Hill Reservoir, F. Bcckwith.

21\%. ARCTIL.M L.

542. A. minus Bernlı. [.t. lappa l. var. minus Gray:]

Several plants with pure white flowers at Garbutt, I. Beckrith.

212a. CARDULS L.

1751. C. CRISPUS L.

Cobbs Hill Reservoir, Miss M. E. Macaulcy.

215. CENTALREA L.

1752. C. NIGRA L.

West Shore Railroad tracks at Pittsford, F. Rouyhton.

1753. ('. americana Nutt.

Long Pond, Killip \& Woodams.

1754. C. maculosa Lam.

Winton road, Brighton, C. C. Lancy.

216. L.APSANA I.. [LAMPSANA HiLL.]

552. I. COMMUNIS L.

Canandaigua, Mrs. E. O. Cartaright.

?18d. HYPOCHAERIS L.

1522. H. RADICATA L.

Waste places around city, C. Vollertsen; Alexander St., near Prince, F. Beckivith.

2181. IEONTODON Banks.

1755. L. Nudrcaulis (L.) Banks,

Eastern part of city, C. Vollertscn.

18e. PICRIS L.

1756. P. HIERACIOIDES L.

Cultivated field, Westfall road, Brighton, C. Vollertsen.

2*3. L.ACTLCA L.

1757. L. SCARIOLA L. var. INTEgRata Gren. \& Godry.

Vacant lots, M. E. Macauley. Becoming common. 
1758. I. canadensis L, var. montana Briton.

B. R. \& P. R. R. near Riversicle, D. M. White.

?:0. CREPIS L.

1759. C. CAPILlaris (L.) WVallr.

Lawns, Rochester, M.S. Baxter.

\section{2. ('. hiennis L.}

Canandaigua, Mrs. E. P. Gardner.

?1!. HIER.ACIL.U I.

1760. H. FloRENTINUM All.

Springwater, Matthea's \& White; Gulick, W. S. Rartir.

1761. H. MLRORUMI.

Canandaigua, Miss E. C. I' ebster.

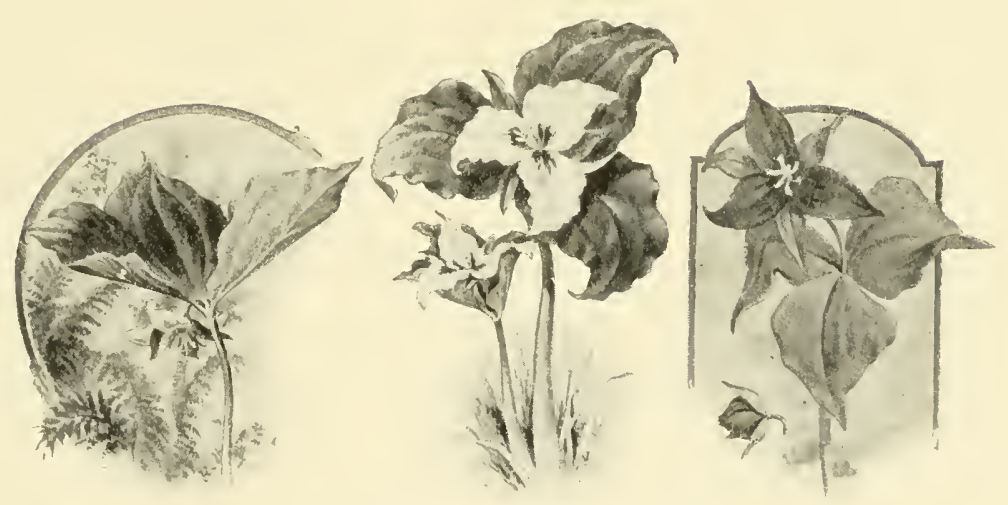




\section{HYMENOMYCETEAE OF ROCHESTER, N. Y., AND VICINITY. \\ By Fred S. Boughton.}

The following Hymenomycetex, or fleshy fungi, numbering 319 species and varieties, were collected by the writer in Rochester. Pittsford, Perinton. Mendon and vicinity. References to the reports of Dr. C. H. Peck are given in parentheses.

\section{CLASS FUNGI.}

Sub-class Basidiom ycetes.

Cohort Hymenomycetes. Gr.-a membrane, a fruit-bearing surface; Gr.-a mushroom.

Family I.-AgaricaCe.E.

Series I.-Leucospor.玉. Gr.-white; Gr.-seed. White spored.

Amanita.

(A name given to some esculent fungi by Galen, perhaps from Mount Amanus.)

1. Amanita phalloides Fr. (Pk. 1895)-phallus-like Amanita. Woods, Rochester, Bushnells Basin and vicinity, common, deadly poisonous.

2. A. phalloides, gray var., same habitat as the last, not common, deadly poisonous.

3. A. verna Bull. (Pk. 1895.) A variety of A. phalloides, not common, deadly poisonous.

4. A. spreta Pk.-hated. Woods, Pittsford, not common, poisonous.

5. A. muscaria Linn. ( $\mathrm{Pk}$. 1895) - Fly Amanita. Poisonous, common throughout the county. The Germans use the caps, immersed in milk, to kill flies.

6. A. Caesarea Scop. (Pk. 1895)-King-like Caesars mushroom. Pittsford. Not common, edible.

7. A. rubescens Pers. (Pk. 1895) -reddish Ananita. Seneca Park, Pittsford, Bushnells Basin, common, edible.

8. A. Frostiana Pk. Pittsford, not common, poisonous.

9. A. sp.-A species new to me. Gray in color, with pileus covered with warts. Woods, Pittsford.

10. A. pantherina DC.-Bushnells Basin, not tested.

11. A. radicata Pk-Rochester, not tested.

12. A. strobiliformis Vitt.-Strobilis, a pine cone. Rochester, edible. 
Amanitopsis Roze.

Amanita. opsis, resembling.

13. Imanitopsis raginata Roze.-iagina, a sheath. Pittsford, not common, edible. Common in the Adirondacks.

14. I. strangulata (Fr.) Roze-choked, from the stuffed stem. Rochester, Pittsford, not common, edible.

15. I. Velosi Pk-zelosts, fleecy. Rochester, Pittsford. Not common; common in the Adirondacks, edible.

16. I. volvata Pk.-possessing a volva. Pittsford, not common, edible.

17. A. nivalis Grev--snowy. Rochéster, too bitter to eat.

\section{LEPIOTA Fr.}

Lepis, a scale.

18. Lepiota nancinoides Pk. (Pk, 1895). Woods, fields, roadsides, edible.

19. L. procera Scop. (Pk. 1895).-Parasol mushroom. Woods, orchards, common, edible.

20. L. Imericana $\mathrm{Pk}$. ( $\mathrm{Pk}$. 1895). Pittsford, not common, edible.

21. L. clypeolaria (Bull.) Fr. (Pk. 1900). Woods, fields and lawns, common, edible.

22. I. acutesquamosa Wein,-acutus, sharp; squama, a scale. Rochester, not common, edible.

23. L. graumlosa Batsch.-granosus, full of grains. Rochester, not common, edible.

24. L. aspera Murrill. Mendon, not common, not tested.

25 L. cepaestipes Sow.-onion-stemmed Lepiota. Pittsford, not common, edible.

\section{Armillaria Fr.}

Armilla, a ring.

26. Irmillaria mellea Vahl. ( $\mathrm{Pk}$. 1895),-honey-colored Armillaria. Around old stumps, common everywhere, edible.

27. I. mellea var.glahra.-smooth. Bushnells Basin, edible.

Tricholoma Fr.

$$
\text { Gr. - a hair; a fringe. }
$$

28. 'Tricholoma personatum Fr. (Pk. 1895) -wearing a mask, (from its many" varieties of colors). Called in England "Blue hats". Woods. common everywhere, edible.

29. T. russula Schaeff. (Pk. 1901).-reddish. Seneca Park, Pittsford, Mendon, Bushnells Basin, edible. 
30. T. gambosmm Fr.-gambosus, swelling near the hoof. Woods, Monroe Co., edible.

31. 'T. vaccinmm Pers.-iacca, a cow. Moods, Monroe Co., cdible.

32. 'T. allum Schaeff. Pittsford, Bushnells Basin, edlible.

33. T. aurantia Schaeff. Fr. Pk. Pittsford, edible.

34. I'. transmutans Pk-changing. Troods, Pittsford, edible.

35. T. tumidellum Pk.-smoky Tricholoma. Woods, Pittsford, edible.

36. T. (olumbetta Fr.-columba, a pigeon, (from the color). Woods, Pittsford, edible.

37. T. subcinereum Pk.--a new species discovered by the writer in a cellar in Fittsford. Pileus about $2 \frac{1}{2}$ inches broad of an ash color, smooth and flat, with broad rounding gills making the pileus look like the half of a ball. Stem three inches high, a little larger than a lead pencil, of the same color as the pileus. Edible, qualities not tested.

38. 'T. snbsiunctum Pk.-partly separated, (from the peculiar manner in which the gills separate from the sten.) Monroe Co., edible.

39. T. imbricatum Fr.-covered with tiles. Rochester, edible.

40. T. subpulverulentum Pers,-slightly dusty. Rochester, edible.

41. T. subpurpura-somewhat purple. Rochester, not tested.

42. T. sejunctum Sow--separated: (from the peculiar manner in which the gills separate from the stem.) Monroe Co., edible.

43. T. terrem Schaeff.-the earth, (from the color). Pittsford, Mendon, Bushnells Basin, quality fair.

44. T. allo-lavidum Pk--yellow-disced. Pittsford, Bushnells Basin, edible.

\section{Clitorybe Fr.}

Gr.-sloping (from the depression of the pileus).

45. C'litocybe odora Bull--odorus, fragrant. Woods, Pittsford, edible.

46. (. multiceps Pk. (Pk. 1909).-multus, many; caput, a hearl, (from growing in clusters). Open places, Pittsford.

47. C. illudeus Schw. (Pk. 1895).-deceiving. Pittsford, Churchville, Golah. Unwholesome. Phosphorescent, giving out light at night.

48. C. intundihuliformis Schaeff. (Pk. 1895).-funnel-formed. Common. throughout the connty, edible.

49. C. cyathiformis Bull-cup-shaped. Pittsford, edible. 
50. C. (Maccaria) ochropurpurea Berk. (Pk. 1906). Woods, Pittsford, edible.

51. C. (Iaccaria) Iaccata Scop. (Pk. 1895), -made of lac. Woods, Pittsford, Mendon, edible.

52. C. (lacearia) laceata, var. pallida Pk. Bushnells Basin, edible.

53. C. (Iaccaria) anetlyctima Bolt.-color of an amethyst. Mendon, not common, edible.

54. C. Mealhata Sow. On lawn, Pitsford, not edible. This mushroom has the property of making the person who eats of it sweat profusely.

55. C. eccentrica Pk. Woods, Monroe Co., not tested.

56. C. allissima Pk. Wonds, Pittsford, not tested.

57. C. gilva Pers.-gili'us, pale brownish yellow. Rochester, edihle.

58. C. monalelpha Mor.-monas, single; adelphos, a brother, from its growing in clusters. Rochester, Pittsford, edible.

59. C. uebularis Batsch.-ncbula, a cloud. Rochester, edible.

60. C. robụsta Pk--robustus, stout. Mendon, edible.

61. C. tuba (Fries) Gill. Pittsford, Bushnells Basin, not tested.

62. C. canticans Pers.-candico, to be shining white. Pittsford, edible.

63. C. sp. species not named. Mendon, Murrill.

64. C. Mlirondackensis Pk. (Pk. 1900). Rochester, edible.

\section{Collybia Fr.}

65. Collybia radicata Relh. ( $\mathrm{Pk}$. 1895). -radix, a root. Woods, fields, lawns, common. Not poisonous, not edible.

66. C. platyphylla Fr. (Pk. 1895).-Gr.-broad; a leaf. Pittsford, Bushnells Basin, edible.

67. C. relutipes.Curt. (Pk. 1895).-rclutim, velvet; pes, a foot. On old logs and stumps, common, edible.

68. C. Intyracea Bull.- butyrum, butter; buttery to the touch. Bushnells Basin, edible.

69. C. dryophila Bull. ( $\mathrm{Pk}, 1907$ ).-Gr.-oak-loving. Woods, common, edible.

70. C. acervata Fr. (Pk. 1908).-accritus, a heap. Bushnells Basin, edible.

\section{Mrcena Fr.}

Gr.-a fungus.

71. Mycena pura Pk. Moods, Pittsford, not tested.

72. M. cohmerems Fries.-adhering together. Rochester, not tested. 
OMPHALIA.

Gr.-belonging to an umbilicus.

73. Omphalia oniscus Fr. Gr.-a wood louse, (from the ashy color). Woods, Pittsford, not common, edible.

74. 0. caespitosa (Bolton) Sacc--growing in clusters. Rochester, edible.

Pleurotus.

Gr.-a side; Gr.-an ear.

75. Plenrotus ostreatus Jacq. (Pk. 1895).-ostria, an oyster. Rochester, Pittsford, Bushnells Basin, common, edible.

76. P. serotinns Fr.-late, from its late appearance. Woods, Pittsford, Bushnells Basin, edible.

77. P. uhmarius Bull. (Pk. 1895).-elm Pleurotus. On logs and stumps, Pittsford, Bushnells Basin, edible.

78. P. sapidus Kalch. ( Pk. 1895).--savory. On stumps and partly decayed trees, Pittsford, Bushnells Basin, edible.

79. P. subareolatus $\mathrm{Pk}$-_somewhat cracking. On living maple tree, Pittsford. Rare, edible.

80. P. petaloides Bull.-petal of a flower. Rochester, not common, edible.

HYGROPHORUS Fr.

$$
\text { Gr.-moist; Gr.-.-to bear. }
$$

81. Hygrophorus pratensis Fr. (Pk. 1895).-pratum a meadow. Pittsford, Bushnells Basin, edible.

82. H. pratensis white var., same habitat, edible.

83. H. cantharellus Schw. Gr.-a small vase. Bushnells Basin, edible.

84. H. cautharellus var, thava. Bushnells Basin, not common, edible.

85. H. ceracens Fr.-cera, was. Monroe Co., edible.

86. II. chrysodon Fr. Gr.-gold, a tooth, (from tooth-like squamules). Monroe Co., edible.

87. H. Ilavo-discus Frost (Pk. 1895).-flavus, yellow; discus, disk. Woods, Palmer's Glen, Rochester, Pittsford, edible. The Boston Mycological Club makes a trip every fall for the express purpose of gathering this species and having it cooked by an expert, a member of the society.

88. H. miniatus Fr. (Pk. 1895),-minium, red lead, (from the color). Woods, Pittsford, Bushnells Basin, edible.

89. H. ehurneus Bull. Fr,-cbur, ivory. Woods, Mendon, edible.

90. H. coceineus Schaeff.-scarlet. Bushnells Basin, edible. 
LACTARIUS Fr.

Giving lac (milk).

91. Lactarims piperatus Fr.-piper, pepper. Rochester, Pittsford, Bushnells Basin; edible but not of first rate quality.

92. I. vellereus Fr,-vellus, fleece. Pittsford, edible.

93. L. deliciosus Fr. (Pk. 1895). Pittsford, edible.

94. L. indigo Schw. IToods, Pittsford, Bushnells Basin, edible.

95. L. luteolus Pk. (Pk, 1902), -yellowish. Pittsford, edlible.

96. L. Merardii Pk. (Pk. 1895). Woods, Pittsford, edible.

97. L. volemus Fr. (Pk. 1895). IVoods. Common; one of the best of fungi.

98. L. trivialis Fr.-common, Rochester, Pittsford, Bushnells Basin. Too peppery to eat.

99. L. lygroploroides B. and C. (Pk. 1895). Seneca Park, Pittsford, edible.

100. L. torminosus Fr,-tomina, gripes. Pittsford, on a lawn, poisonous.

101. L. chelidonium Pk. Rochester, edible.

102. I. crocea Burlingham. Rochester, not tested.

103. I. iusulsus Fr.-tasteless. Rochester, edible.

104. L. atro-riridis Pk.-black green. Woods, Pittsford, not tested.

105. L. Inliginosus Fr,-fuligo, soot. Rochester, Pittsford, Bushnells Basin, poisonous.

106. L. theiogalus Fr. Gr.-brimstone; milk. Rochester, Pittsford, Bushnells Basin, edible.

107. L. pergamenus Fr.-parchment. Rochester, edible.

108. L. griseus Pk.--gray, Pittsford, not tested.

109. L. liguyotus Fr.-lignum, wood. Rochester, edible.

110. I. sulpurpureus Pk,-somewhat purple. Rochester, Pittsford, not testerl.

\section{Russula Pers.}

Reddish.

111. Russula purpuriua Quel, and Schulz.-purple. Woods, Pittsford, edible.

112. R. nordida Pk. (Pk. 1905),-dingy. Rochester, Pittsford, Bushnells Basin, eclible. 
113. R. ochrophylla Pk. (Pk. 1895). Seneca Park, Pittsford, Bushnells Basin, edible.

114. R. viresceus Fr. (Pk. 1895), -vircsco, to be green. Common but not as plentiful as one could wish. Edible, one of the best.

115. R. citrina Gillet.-citron colored. Pittsford, edible.

116. R.cyanoxantla (Schaeff.) Fr. Gr.-blue; Gr.-yellow, from the color. Bushnells Basin, Adirondack Mts., not common, edible.

117. IR. foetens Fr,-stinking. Woods, common, not edible, not poisonous

118. R. emetica Fr.-an emetic. Pittsford, edible, though reputed to be poisonous by some.

119. R. atro-purpurea $\mathrm{Pk}$--atrc, black; purpurcus, purple. Pittsford. Edible, must be eaten as soon as gathered.

120. R. anrata Fr.-aurum, gold. Pittsford, Bushnells Basin, edible.

121. R. alutacea Fr,-aluta, tamned leather. Bushnells Basin, edible.

122. R. rosiepes (Secr.) Bres.-rosa, rose; pcs, a foot, (from the color of the stem). Seneca Park, Pittsford, Bushnells Basin, edible.

123. R. compacta Frost. (Pk. 1906).-compact, firm. Seneca Park, Pittsford, Bushnells Basin, edible.

124. R. olscura Pk. Bushnells Basin, Adirondack Mts., edible.

125. R. variata Banning ( $\mathrm{Pk}$. 1905).-variable. Seneca Park, Bushnells Basin, Pittsford, edible.

126. R. crustosa Pk. (Pk, 1902). Bushnells Basin, edible, rare.

127. K. sp. new species, not named, found in Mendon. Has a very viscid pileus. Murrill.

128. R. hicolor Burlingham.-two colored. Rochester, edible.

129. R. lactea Fr.-lac, milk. Rochester, edible.

130. R. rubra Fr.-rubcr, red. Rochester, Pittsford, Bushnells Basin, edible.

131. R. Wectinata Fr.-pecten, a comb, (from comb-like furrows on the margin). Edible but not very good.

132. R. decolorans Fr. $-d c$ and coloro, to color. Bushnells Basin, edible.

133. R. alhella Pk,-whitish. Pittsford, edible.

134. R. inreata Fr.-furca, a fork, (from the forked gills). Pittsford. edible.

135. R. pinophila Pk.-pine loving. Rochester, Adirondack Mts., edible. 


\section{Cantharellus Adans. \\ Gr.-a vase; a cup.}

136. Cantlaarellus cibarins Fr,-cibaria, food, Seneca Park, Pittsford, Bushnells Basin, Adirondack Mts., common. One of the highestpriced mushrooms sold in the English markets.

137. C. anrantiacus Fr,-orange yellow. Bushnells Basin, Adirondack Mts., edible.

138. C. cinnabarino Pk-cinnabar red. Rochester, Pittsford, Bushnells Basin, edible.

139. C. hrevipes Pk.-brevis, short; pes, a foot. Rochester, edible.

$$
\begin{aligned}
& \text { Marasmius Fr. } \\
& \text { Gr.-to wither or shrivel. }
\end{aligned}
$$

140. Marasmins oreades Fr. (Pk. 1895). Fairy Ring, Mountain Nymphs, Scotch Bonnet. Common in fields and orchards. A very valuable edible species which should be better known. Can be dried for winter use.

141. M. Wynnei B. \& Br. Woods, Pittsford, edible, not common.

142. M. siccus (Schw.) Fries. Rochester, not tested.

$$
\text { LeNTiNus Fr. }
$$

Lentus, tough or pliant.

143. Lentiuns lepideis Fr.-Gr.-scaly. Railroad ties, Pittsford, edible.

$$
\text { Panus Fr. }
$$

A name given to a tree-growing fungus by Pliny.

144. Paums forulosus Fr.-a tuft of hair, (from its hairy pileus). Rochester, Pittsford, edible.

145. P. stypticus Fr,-stypticus, astringent. Bushnells Basin, poisonous.

$$
\begin{aligned}
& \text { Schizophyllum Fr. } \\
& \text { Gr.-to split; } G r \text { - a leaf. }
\end{aligned}
$$

146. Schizophyllnm commune Fr. On decaying wood, not edible.

Series II.-Rhonosporæ. Gr.-rose; Gr.-a seed. Spores pink or salmon color.

$$
\text { Volvarta Fr. }
$$

Volica, a wrapper

147. Volvaria volvacea Bull.-zolia, a wrapper. Rochester, edible.

148. V. volvacea white variety found by the writer, edible, rare. 
149. V. bombycina Schaeff.-bombyx, silk. On three living trees in Pittsford; edible, not common. A large and very conspicuous object with immense white pileus and pink gills and long silky white hairs on the pilens, making it look not unlike a Tam O'Shanter cap.

\section{Pluteus Fr.}

Plutelts, a shed (from the conical shape of the pileus).

150. Pluteus cervinus Schaeff.-cervus, a deer, from the color. Stumps in woods and old sawdust piles, Pittsford, edible.

151. P. graunlaris $\mathrm{Pk}$.-sprinkled with grains. Rochester, edible.

152. P. admirahilis $\mathrm{Pk}$. Rochester, edible.

$$
\begin{gathered}
\text { Entoloma Fr. } \\
\text { Gr.-within; Gr._a fringe. }
\end{gathered}
$$

Probably referring to the innate character of the psendo-veil.

153. Entoloma grande $\mathrm{Pk}$. Bushnells Basin, edible.

154. E. sinuatum Fr.-waved. Pittsford, poisonous.

$$
\begin{gathered}
\text { Clitopilus Fr. } \\
\text { Gr.-a declivity; } G r \text {.- a cap. }
\end{gathered}
$$

155. Clitopilus pronullus Scop. (Pk. 1895).-prunus, plum. Rochester, Pittsford, Mendon, edible.

156. C. orcella Bull. (Pk. 1895). Woods, Pittsford, edible.

157. C. noveboraceusis Pk.-New York Clitopilus. Woods, Pittsford, edible.

158. C. norehoracensis var. tomentosipes Pk.-hairy stemmed. Pittsford, edible.

159. C. caespitosus Pk-tufted. Rochester, edible.

Clatbopus Smith.

Claudus, lame; pous, a foot.

160. Clandopus nidulaus Pers.-midus, a nest. Bushnells Basin, edible.

Series III.-Ochrospor.玉. Spores brown.

$$
\begin{gathered}
\text { Pholiota Fr. } \\
\text { Gr.-a scale. }
\end{gathered}
$$

161. Pholinta praecox Pers. (Pk. 1895),- -early. Fields, lawns, roadsides. Rochester, Pittsford, edible.

162. P. sumarrosa Mull. (Pk. 1901).-squarrosus, scurfy. On logs, Pittsford, edible. 
163. P'. ('omosal Pk. Pittsford, not tested.

164. P. vermillua Pk. (Pk. 1903).-wormy. Uncler an apple tree, Pittsford, not tested.

165. P'. durns Bolt.-durus, hard. Rochester, edible.

$$
\begin{gathered}
\text { INocyBe. } \\
\text { Gr.-a fiber; Gr.-a head. }
\end{gathered}
$$

166. Inorylue moduta Pk. A new species discovered by the writer in the Pittsford cemetery, with small modest brown pileus and stem. Not edible.

167. I. reophylla (Sow.) Fr. Rochester, not edible.

168. I. genpluyla var. purpura, not edible. A pretty purple variety found by the writer in woods, Pittsford.

169. I. Lorillardiana Murrill. Rochester, not edible.

$$
\begin{gathered}
\text { Hebeloma Fr. } \\
\text { Hebe, youth; loma, a fringe. }
\end{gathered}
$$

170. Hobeloma fastibile Fr.-fastidibilis, loathsome, (from the smell). Rochester, Pittsford, not edible.

171. H. crustiliniforme Bull-crustulum, a small pie; forma, form. Rochester, not edible.

172. H. -1.- - a species found by the writer in Mendon, said by Dr. Murrill to be new.

\section{Flammela Fr.}

Flamma, a flame (In reference to the bright colors of many of the species).

173. Flamunia aluicola Fr.-alnus, alder; colo, to inhabit. Near a hedge, Pittsford, edible.

17t. F. decmrens Pk. Monroe Co. Not tested.

175. F. silphurea Pk. (Pk. 1911) Monroe Co. Not tested.

$$
\begin{aligned}
& \text { Naucoria Fr. } \\
& \text { Vancum, a nut shell. }
\end{aligned}
$$

176. Nancoria semi-orlicularis Bull,-half round. Lawns, Rochester, Pittsford, common, edible.

177. X. platy-perma Pl.-platys, broad; sperma, a seed. Lawns, Pittsford, edible.

178. X. pediades Fr. Gr.-a plain. Rochester, edible. 
Galera Fr.

Galerus, a ca!n.

179. Galera tenera Schaeff.-tener, tender. Lawns, Pitsford, edible.

180. O. flava Pk--flar'us, yellow. Pittsford, edible.

181. G. reticulata Ph. Pittsford, rare, not tested.

Crepidotus Fr.

Gr.-a slipper.

182. Crepidotus versutus Pk. Rochester, not tested.

Cortinarius Fr.

Cortina, a veil or curtain.

183. Cortinarius alho-violacens Pers. Seneca Park, Pittsford, edible.

184. C. sanguinens Fr.-sanguis, blood. Woods, Pittsford, Bushnells Basin, edible.

185. C. cimnamomeus Fr. ( $\mathrm{Pk}, 1895$ ). Woods, common, edible.

186. C. rnbripes Pk.-red stemmed. A new species discovered by the writer in what is now Lombs woods, Pittsford. Pileus pale tan color, gills rich purple, stem swollen at the base like a radish and ' of a brick red color. Not common and not tested.

187. C. semi-sanguineus Pk. (Pk. 1895),-partly red. Bushnells Basin, edible.

188. C. sebacrus Fr.-sebum, tallow, from the color. Bushnells Basin, edible.

189. C. napus Fr. Pittsford, not tested.

190. C. distans Pk. Woods, Bushnells Basin, not desirable.

191. C. infractus (Pers.) Fries. Pittsford, not tested.

192. C. purpurascens Fr. Bushnells Basin, edible.

193. C. turbiuatus Fr.-turbo, a top. Pittsford, edible.

Paxillus Fr.

Parillus, a small stake.

194. Paxillus involutus (Batsch) Fr.-rolled inward. Seneca Park, Bushnells Basin, edible.

195. P. atro-tomentosus (Batsch) Fr.-ater, black; tomentum, down. Forest Lawn, edible.

196. P. rhodoxanthus Pk. Rochester, not tested. 
Series IV.-Porphyrosporæ: (Pratelli). Gr.-purple.

\section{Agaricus}

Agaricon, a Greek name for fungi, said to be derived from the name of a town, Agara.

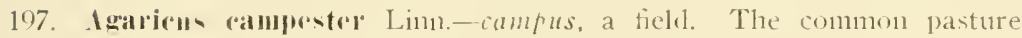
mushromm; fields, orchards, roadsides, edible.

198. 1. diminutious Pk. (Pk. 19)(0)). Pittsford, Adirondack Mlts., edible.

199. 1. Rodmani Pk. (Pk. 1895). Roadsides, Pittsford, common, edible.

200. 1. manitirus Pk. Roadsides, Pittsford, erlible, not common.

201. 1. Silvieola Vitt. (Pk, 1895).-siléa, a wood; colo, to inhabit. W'oorls, Pittsford, edible.

202. 1. Wacemyer Pk. (Pk. 1895). Woods, orchards, lawns, common, edible.

203. 1. Sylvations Schaeff. Woods, Forest Lawn; orchards, Sodus, edible.

204. 1. abuptibulhus Pk. (Pk, 1895). (.t. sitzicola Vitt. A. arvensis var. abruptus Pk.) This being the wood cousin of the field mushroom is worth notice. It grows very tall with a large bulb at the base of the stem and a large pileus, and from a distance looks like Amanita phalloides. It has the true mushroom flavor. Found in woods in Pittsford, not common.

$$
\begin{aligned}
& \text { Stropharia. } \\
& \text { Gr-id sword beit (referring to the ring). }
\end{aligned}
$$

205. Ntropharia aeruginosa Curt.-arugo, verdigris, from the color. Not edible.

\section{HYPHOLOMA.}

$$
\text { Gr.-a web; Gr.-a fringe. }
$$

206. Hyphofoma incertum Pk. (Pk. 1895). Lawns, roadsides, common, edible.

207. H. ageregatmu sericenu Pk. Same habitat as the last and like it, but larger, edible.

208. H. Perpluxum Pk. (Pk. 1895). Around old stumps, common everywhere, edible.

209. H. sublateritinm Schaeff,-sub and later, a brick, from the color. Same habitat as the last, edible.

210. H. Bonghtoni Pk. (Pk. 1909). A new species discovered by the writer in woods at Bushnells Basin. Pileus from two to four inches broad often areolately cracking, pale reddish brown, lamellae unequal purplish brown, seal brown or blackish-stem equal, white or whitish, two to three inches long. Not tester, but Dr. Peck says probably edible. 
211. H. appendiculatum Bull.-a small appendage (from fragments of the veil adhering to the pileus). Rochester, Pitsford, edible.

212. H. Candolleamm Fr. Rochester, edible.

213. H. rigidlipes Pk-rigid stemmed. Rochester, Pittsford, not tested, prohably edible.

\section{Psilocybe Fr.}

Gr.-naked; head.

214. Prilocybe atomatoides Pk. Pittsford, not tested.

Series IT.-Melaxospor.E (spores black). Gr.-black; Gr.-seed.

\section{Coprinus Pers.}

$$
\text { Gr.--dung. }
$$

215. Coprinus micaceus (Bul1) Fr.-mica, grain, granular. Glistening Coprinus or brownie mushroom; common everywhere, edible.

216. C. comatıs Fr.-coma, hair. Shaggy mane mushroom. Lawns, waste places, common everywhere, edible.

217. ('. atramentarius (Bull) Fr.-atramentum, ink. Inky Coprinus. Same habitat as the last; one of the best.

218. ('. virgiueus Banning. Rochester, edible.

$$
\begin{gathered}
\text { Pandolus Fr. } \\
\text { Gr-all; Gr.-variegated. }
\end{gathered}
$$

219. Panaeolns nolidipes Pk,-solid stemmed. Rochester, Pittsford, edible.

220. Panaeolns epymices Pk. Monroe Co., not tested.

$$
\begin{gathered}
\text { Psathirella. } \\
\text { Gr.-fragile. }
\end{gathered}
$$

221. Psatlyrella disseminata Pers.-dissemino, to scatter. Rochester, Pittsford, common, edible.

Family II.-POLYPORACE.T.

$$
\text { Boletixus Kalch. }
$$

222. Boletiums pictus Pk--spotted. Sullivans, edible.

223. B. porosus (Berk) Pk. Rochester, Pittsford, edible.

224. B. grisellus Pk. Pittsford, not tested.

Boletus Dill.

$$
\text { Gr.-a clod. }
$$

225. Boletus gracilis Pk. Bushnells Basin, edible.

226. B. Mmericanıs Pk. Monroe Co., edible. 
227. B. subluteus Pk. (Pk. 1895), -somewhat yellow. Bushnells Basin, edible.

228. 13. subtomentosms L.-somewhat hairy. Monroe Co., edible.

229. 13. bicolor Pk.-two colored. Woods and open places, Pittsford, edible.

230. B. Russelli Frost. Bushnells Basin, not common, edible.

231. IB. edulis Bull. (1'k. 1895). Woods, Rochester, Pittsford, l'ushnells Basin, edible.

232. B. elulis var, clavipes Pk.-club footed. Rochester, Pittsford, edible.

233. 13. Imidus Schaeff. Moods, Pittsford. Should be carefully tested.

234. B. versipellis Fr. (Pk. 1895). Bushnells Basin, Bergen Swamp, edihle.

235. 13. Pellens Bull. (Pk. 1895). Rochester, Pittsford, unwholesome.

236. B. grisells Frost--gray. Bushnells Basin, edible.

237. B. chromapes Frost. Nonroe Co., edible.

238. B. communis Bull, Monroe Co., not tested.

239. B. retipes B. and C.-reticulate stem. Bushnells Basin, edible.

240. 13. castamens Bull.-chestnut. Rochester, Adirondack Mts., edible.

241. B. impolitus Fr.-mpolished. Rochester, edible.

242. B. rermiculosms Pk.-wormy. Rochester, not tested.

243. 13. subanrens Pk. var. rubro-scriptus Pk. Rochester, edible.

244. B. subtomentosms L.-somewhat downy. Rochester, edible.

245. 13. sp.- - a new species found by the writer in Bushnells Basin. Small peach yellow pileus with red cheek. Dr. Peck said that it was new but on account of not finding any more specimens he would not give it a name.

246. B. Sullivantii B. and M. Rochester, not tested.

Strobilomyces Berk.

Gr.-a pine cone; a fungus.

247. Strobilomyces strobilacens Gr.-cone like. Rochester, Pittstord, Bushnells Basin, edible.

\section{Fistulina Bull. \\ Fistula, a pipe.}

248. Fistulina hepatica (Huds.) Fr.-resembling the liver. Beefsteak mushroom. On chestnut stumps. Rochester, Pittsford, edible.

249. F. pallida B. and Rav.-pallidus, pale. Rare, not tested.

POLYPoRus Fr.

$$
\text { Gr.-many; a passage. a pore. }
$$

250. Polyporus squamosns Fr,-squamma, a scale. On partly decayed trees, Pittsford, edible but tough. 
251. P. umbellatus Fr.-umbella, a sun shade. Woods, Pittsford, edible.

252. P. sulphureus Fr. (Pk. 1895). - sulphury Polyporus, chicken mushroom. Rochester, Pittsford, Mendon, Perinton.

253. P. pieipes Fr.-pix, pitch: pes, a foot. Monroe Co., edible.

254. P. poripes Fr.-porus-stemmed. Woods, Pittsford, edible.

255. P. anax Berk. Woods, Pittsford, edible.

256. P. lucidus Fr. Monroe Co. Not tested.

257. P. iroudosms Fr.-frons, a leafy branch. Pittsford, edible.

Family III-HYDXACE.

$$
\begin{gathered}
\text { Hronum. } \\
\text { Gr. - name for some edible fungus. }
\end{gathered}
$$

258. Iydumm repandum L. ( Pk. 1895), -spreading. Seneca Park, Pittsford, edible, common but not plentiful.

259. H. albidum Pk. (Pk. 1895). Noods, Pittsford, edible.

260. H. coralloides Scop) (Pk. 1895). Pittsford, Fairport, Adirondack Mountains. A handsome plant, edible.

261. H. calput-ursi Fr. (Pk, 1895).--bears hearl Hydnum. Pittsiord, Adirondack Mts., edlible. This can be truly called a wonderful plant with its resemblance to the head of a polar bear.

262. H. caput-Medusae Bull--Merlusa's head Hydnum. Mendon, Adirondack Mts., edible. This with its long spines is a handsome plant.

263. H. erinacem Bull.-crinaccus, a hedgehog. Pittsford, edible.

264. H. scabrosum Fr.-scabrosus, rough. Rochester, edible.

265. H. imbricatum L.-imbrer, a tile. Woods, Pittsford, edible.

Family IV.-Thelephorde.e Fr.

Gr.-a teat; Gr.-to bear.

\section{Craterellus Fr. \\ Crater, a bowl.}

266. Craterellux cormeopoides Pers. (Pk. 1895).-cornucopia shaped. Pittsford, Bushnells Basin, edible. A remarkable mushroom, looking not unlike a small ruffled-edge morning glory blossom, of a pinkish brown color.

267. C. cantharellus Schw,--a small vase or cup. Rochester, edible. In looks somewhat like a chantarelle. 
Family V.-Clavariaces.

$$
\begin{aligned}
& \text { SPARASSIS Fr. } \\
& \text { Gr. - to tear in pieces. }
\end{aligned}
$$

208. Sparassis crispa Fr-crispus, curly. Pittsford, edible. A very remarkable mushroom looking not unlike a coil of two to four inch wide brown ribhon set on elge and somewhat crimperl. It is not commons.

\section{CLAMARIA L. \\ Cla $\imath^{\wedge} \alpha$, a club.}

209. Clavaria Ilava Schaeff.-yellow. Seneca Park, Pittsford, Bushuells Basin, exlible.

270. (. botrytes Pers. (Pk. 1895), - a cluster of grapes (from shape). Bushnells Basin, edible.

271. C. ametlystina Bull,-amethyst color. Pittsford, edible.

272. ('. cristata Pers. (Pk. 1895). Scneca Park, Pittsford, exlible.

273. I. coralloides L.-coral like. Pittsford, edible.

274. ('. iormona Pers.-neat, handsome. Pittsford, edible.

275. C. stricta Pers.-stringo, to draw tight. Bushnells Basin, edible.

276. ('. anrantio-cinnaluarino Sclww--orange, vermillion. Bushnells Basin, edible. This is the handsomest of this family, looking like a branch of red coral.

277. ('. rermicularis Scop.-urmis, a worm. Bushnells Basin, Sullivans. rare, edible. First found by the writer in the Adirondacks.

278. C. Insiformis Sow--fusus, a spindle. Pittsford. Adirondack Momntains, edible.

279. ('. pistillaris L. (Pk. 1904)._pistillum. Woorls, Pittsford, edible.

280. 1. pyxidata Pers.-pyis, a small box, Bushnells Basin, edible.

281. C. Mensa Pk. Bushnells Basin, edible.

282. 1'. pinophila Pk- - pine-loving. Pittsford, not tested.

28.3. C. mucida Pers-moss like. Rochester, Pittsford, not tested.

Family VI.-TreMrLlace. Fr.

Sub-family TREMELINE.E.

\section{TREMELLA Dill. \\ Trcmo, to tremble.}

284. Tremella myertophila Pk. Bushnells Basin. Parasitic on Collybia dryophila; edible. It is sometimes so heavy as to weigh the caps to the ground.

285. I. Inciönmis Berk. Monroe Co., not tested. 
Tremellodon Pers.

Tremo, to tremble.

286. Tremellodon gelatinosum Pers.-jelly. Monroe Co., edible.

Sub-class.-Ascomycetes.

Cohort Discomycetes Gr.-a sac; Gr.-a fungus.

Family Helvellacer.

\section{Helvella Linn.}

287. Helrella crispa Fr.-curled. Bushnells Basin, edible.

LEOTIA Hill.

288. Leotia Inbrica Pers._slippery. Bushnells Basin, edible.

Morchella Dill.

Gr.-a mushroom.

289. Morchella conica Pers. (Pk. 1895). Pittsford, Bushnells Basin, edible.

290. И. esculenta Pers. Pittsford, Bushnells Basin, edible. Sold in stores of some of the IVestern states.

291. M. deliciosa Fr. Pittsford, edible.

292. I. semilihera DC.-half free from the stem. Bushnells Basin, edible.

\section{Gyromitra $F r$.}

293. Gyromitra esculenta Fr. Rochester. Edible for some, unwholesome for others; use with caution.

294. G. brumnea Underwood.-brunneus, brown. Pittsford, edible.

\section{Spathularia Pers.}

A Spatula.

295. Spathularia charata (Schaeff.) Sacc-club shaped. Bushnells Basin, Adirondack Mts., edible.

$$
\text { Geoglossum Pers. }
$$

(Emended)

296. Geoglosinm glutinosnm Pers. Rochester, edible.

Family.-PEzız.ङ.

\section{Peziza Linn.}

297. Peziza hallia Pers,-bay or brown. Rochester, Pittsford, edible.

298. P. anrantia Pers.-orange-colored. Rochester, Pittsford, edible. 
299. P. fercinea Jacq.-scarlet. On fallen branches in woods, Pittsford, edible. A bright searlet mushroom coming with the early wild flowers and looking mucli like one.

300. P. sp. A species found by the writer in woods, Pittsford, growing in clusters with stem long and pileus two inches across of a beautiful orange color on top and white underneath. This was sent to Dr. Peck but he could not identify it and no more having since been found it remains mnnamed

301. I. unicisa Pk--implying one incision. A single plant found by the writer in the Catskill mountains. About four inches high of a yellow color tinged with pink and split down one side. I afterwards found one in Meinclon. Edible.

$$
\begin{aligned}
& \text { URNULA Fr. } \\
& \text { Gr-burned. }
\end{aligned}
$$

302. Irnula craterium (Schw.) Fr.-a small crater. Pittsford, Sullirans. This is a very remarkable plant of the shape and size of an old fashioned wine-glass. Pilcus dull black inside, ash white outside. Found but twice by the writer.

\section{Butgaria Fr. \\ Found first in Bulgaria.}

303. Bulgaria inquinan: Pers.-befouling or polluting; so called because of the blackish gelatinous coating of the pileus. This is a small cupshaped fungus black inside and dark brown or chocolate colored ontside. Pittsford, not very common. Not tested.

Cohort.-Pyrenomycetes.

Family:-Hypocreacer.

$$
\begin{gathered}
\text { Hypomyces Fr. } \\
\text { Gr--under; Gr.-fungus. }
\end{gathered}
$$

304. Hyponyces lactillursum (Schw.) Tulasne.-lac, milk; fluorum, flowing. This is a remarkable parasite on Lactarius piperatus, changing that mushroom from white to orange scarlet color, removing the gills, adding to the weight and from being a second rate mushroom making it one of the best.

305. H. purpureus Pk. Bushnells Basin, edible.

306. H. Iateritius Pk. Parasitic on Lactarius indigo. Bushnells Basin, rare, edible.

307. H. Hyalinus (Schw.) Tul. Monroe Co., not tested. 
Peckiella Sacc.

308. P. Banningiar (Peck) Sacc. Bushnells Basin, rare, not tested.

Sub-class Basin10.11 Yetes.

Cohort Gastrompetes.-Gr.-gasteron, a sac.

Family T.-PHALLOIDE.

\section{Phateles Mich.}

309. Phallus Ravenelii B. and C. Kochester, Pittsfurd, edible when in the egg state. Has a very bad odor when full grown.

\section{MUtinus Fr.}

310. Mutiuns canium Fr. (Phallus caninus Berk.; P. inodorus Sow.) Rochester, Pittsford, edible in the egg state.

Family II.-LyCOPERDACE. $¥$.

\section{Geaster Mich.}

$$
\text { Gr. - the earth; Gr.--a star. }
$$

311. Cieaster hygrometricus Pers. Pittsford, edible when young. This fungus is known as being a natural barometer, spreading its stellate covering on the ground when moisture is in the air, and closing it around its puffy body when humidity is absent.

\section{Tylostoma Pers.}

$$
\text { Gr.-a knoh. }
$$

312. Tylostoma myeniamm K1. Rochester, Pittsford, edible. This species is noted for having the entire peridium mounted on the apex of the stem.

\section{Calvatia Fr.}

313. ('alvatia gigantea Batsch. (Lycoperdon borista Linn; L marimum Schaeff; L giganteum Batsch.) Rochester, Pittsford, edible. One weighing 58 lhs. was found in Rochester a few years ago.

314. (. (yathiformis Bosc--cup shaped. Pastures, orchards, Pittsford, Bushnells Basin, common, edible.

\section{LiTOPERDON Tourn.}

315. Lyenperdon Frostii Pk. Woods, Pittsford, edible. This fungus reminds one of a chestnut burr when ripe and brown, edible.

316. I. Dyriorme Schaeff,--pear formed. Pittsford, Adirondack Mts., edible. 
317. L. Dedicellatum Pli-pediculus, a little foot. Bushnells Basin, edible.

318. L. gemmatum Batsch,-gemmed. Rochester, edible.

Family III.-SCLeronermacex.

\section{Sclerolerma Pers.}

Scleros, hard; dermos, skin.

319. Sclerolerma vulgare Fr.-zulgaris, common. Common everywhere, edible when young and white.

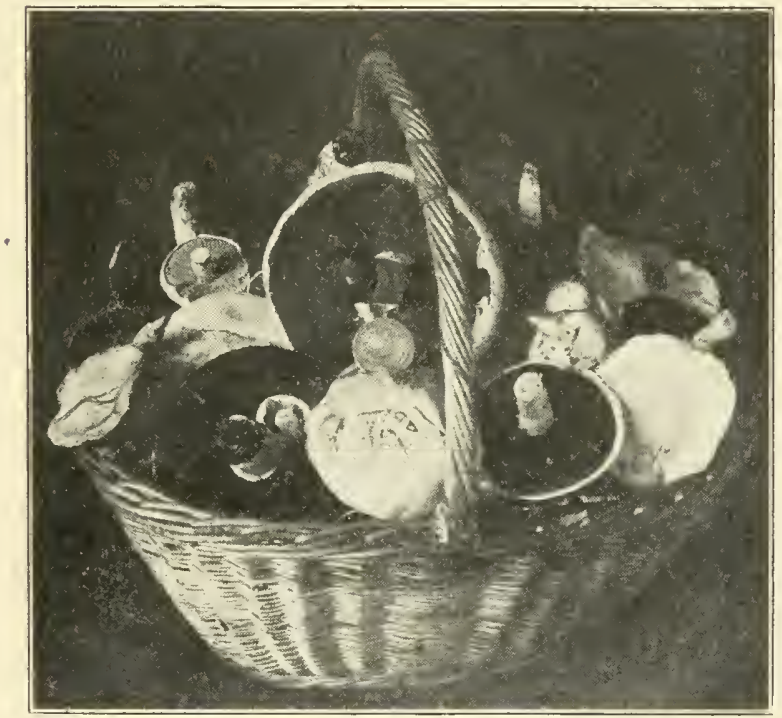




\section{INDEX TO URDERS AND GENERA.}

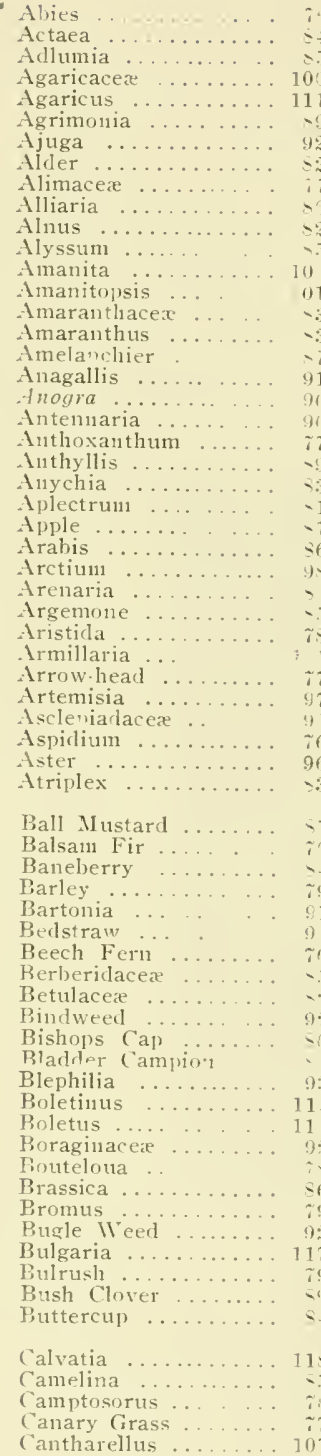

Carifoliacere ........ 94

Cardamine ..........

Carduus ........... 95

Carex .............

Carya $\ldots \ldots \ldots \ldots \ldots$.

Caryophyllacex ...... -

Catchfly ........ -

Celtis ..............

Centaurea ..........

Chenopodiaceæ ....... -3

Chenoporium .......

Chimaphila ...... . 9

rhrysothamnus ..... 95

Cinquefoil ......... n

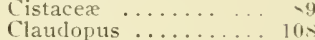

Clavaria ............ 11.

Clavariacex ......... 117

Cliutonia ... ....

Clitocybe ......... 10

Clitopilus .......... 10,

Club Joss .......... it

Collybia ......... 10:

Compositæ ........ $9 . \bar{J}$

Conringia ..........

Convolvulacere ......

Convolvulus ....... 92

Coprinus

Corallorrhiza ..... -1

Coral Root ....... . . -

Corky Elm .........

Cornacere ......... !1

Cornus ............ 91

Cortinarius .......... 110

Cotton Grass ....... 79

Crataegus .......

Craterellus ........ 114

Crepidotus ......... 110

Crepis ..........

Cruciferx ............

Cuscuta .......... 9

Cynancluun ........ 92

Cynoglossum ....... 92

Cynosurus ....... is

Cyperacex...$\ldots \ldots$ i

Cyperus .........

Dalibardia .........

Dead Nettle .... .

Desmodium ..... .

Dipsacaceæ .......

Disporum .......... -

Dodder ............

Dogwood .......... 91

Drop-seed ........ is

Dyssodia .........

Eleocharis ........

Elm .............

Entoloma ......... Ins

Epilobium .......... 90

Enipactis ........

Eragrostis .........

Frirater .... (1)

Frin horum ...

Eupatorium ........

E.mbor ia .... in

Euphorhiacere
Evening Primrose .... 90 Everlasting $\ldots \ldots \ldots .96$

False Flax ..........

Feather Grass ....... 77

Fescue Grass ……

Festuca ...........

l.1gwort $\ldots \ldots . . . \cdots \cdot 93$

Fistulina ........ 11:

Flanmula ......... 109

Fumariacex ............

Galeopsis ....... . $9: 3$

Galera .......... 110

Galium .... ..... $9 t$

Gaura ........... 91

Geaster ...........118

Gentiana ..........9. 9]

Gentianacex .......... 91

Geogiossum .......... 116

Geraniacex ......... s9

Geranium ......... s9

Geum .......... ss

Globeflower ......... st

Glyceria $\cdots$ is

Gnaphalium .......... 97

frolden seal ......... it

Grama Grass .......

Gramilee ......... i

Green Briar ......... si

Green Violet . ..... g.

Griudelia

Gutierrezia ........

Gymnolomia ....... 97

Gy romitra . . . . ..... 110

Habenaria ......... 1

Hackherry ... .......

Hardliack ......... si

Hawthorn ... ..... -

Hebeloma .......... 109

Hedqe Iustard .......

Heliantlus ......... 97

Heliopsis ......... 97

Helvella .......... 110

Hemp Vettle ........ 93

Hesperis .......... 6

Heteranthera ......

Hickory .......... -2

Hieracium . . . ! ! !

Hierochloe ......... i⿱

Holcus .......... is

toly Grass ......... T

Hordeum ..........

Iloustouia ........ 9

Hvbanthus ... . . ... 90

Hydnacex ........ 11

ryonum .......... 11 t

Hydrastis ......... of

Hygropliorus ......... 104

Hymenomyceter .... 100

Hyoscyamus ....... 93

Hypholoma ........ 111

Hy pochaeris ....... 98

Hypocreacex ......... 117

Hypomyces ........ 111

Illecebraceæ $. . \ldots \ldots . \$ 3$

Inocybe ......... 10 s 
Teffersonia $\ldots, \ldots \ldots \ldots$

Juglandacea $\ldots \ldots \ldots \ldots$

Juneberry .........

Knautia ......... 95

Kochia ...........,

Labiate $\ldots \ldots \ldots \ldots \ldots$ 9.2

l.actarius $\ldots \ldots \ldots \ldots$. 10.3

Lactuca ........... 9.

Latlies' Tresses ...... - 1

Lamium .......... 93

Lampsana $\ldots \ldots \ldots \ldots$ s

Lechea .............. vo

Leguminosx ........ -

Lentinus .......... 107

Leontodon ......... 9.

Leotia ........... 11

Lepidium .........

Lepiota ......... 101

Lespedeza .........

Liliaceæ .......... so

Linaria..$\ldots \ldots \ldots \ldots .9$

Liparis ........... $=1$

Lobularia ......... s.

Lychnis ......... n

Lycoperdacea …..... 118

1.ycoperdon ......... 11

Lycopodiacex ........ if

Lycopodium ........ $i 6$

Lythracea $\ldots \ldots \ldots \ldots .90$

1.ythrum ........ 90

Machaerauthera .....

Malus .............

Mamna Grass ....... i

Marasmius ........ 10

Matricaria .......... 97

Mleadow Grass ....... is

Vitella .......... -

Monarda .......... 93

Norchella .......... 119

Ilud Plantain ...... on

Tuhlenbergia ...... is

Mullein Pink ........ o.

II ustard ......... is

Mlutiuus ............ 11 .

Mlycena .......... 103

Xajadacere .........

Vajas ............... is

Vasturtium ........

Naucoria ......... 100

Neslia .............

Vettle ............ $=3$

Nightshade ........ 93

Oenothera ........ 9i)

Omphalia ............ 10t

Onagracese ............ on

Onoclea .............. $\tau_{6}$

Onosmodium ........ 9:

Orchidacex ........ -

Oxalidacex...$\ldots \ldots$ s. $s$

Oxalis ...........

Panaeolus ........ 112

Panicum .......... it

Panus ............. 1n $^{2}$

Papavaracere ....... \& l'aspalum $\ldots \ldots \ldots \ldots$ \%

l'axillus ......... 119

l'earlwort ......... st

Peckiella .......... 118

Pelicularis ....... 94

Penny Cress ....... s.j

l'entstemon ........ 94

Peziza ........... 116

Peziza...$\ldots \ldots \ldots \ldots .116$

Phalaris ............ 77

Phalloiclex .......... 11s

l'hallus ........... 11s

Phegopteris ........ if

P'holiota .......... 10 (1)

Phragmites ........ is

Ticris ............ 98

Pigweed ......... 83

P'impernel ......... !) 1

l'inacee .........

P'itcher Plant .. .

Plantaginace ........ 94

Plantain $\ldots \ldots \ldots \ldots \ldots \ldots . .9 \%$

Pleurotus .......... 104

Plutens .......... 10

Poa ............ is

Polemoniaces ........ $9 \cdot$

Polemonium ....... 92

Polymnia .......... 97

Polypodiacere ....... $\pi$

Polyporacex ........ 112

Polyporus .......... 113

Pontederiaceze...... st

Potentilla ......... ss

Prickly Poppy ...... 8.5

Primulacee..... .91

Psathyrella ....... 112

Psilocybe ........... 112

Putty-Root ......... s1

Pycuanthemum ...... 93

Pyrola ............ 91

Radicula ......... 86

Raggerl Robill ......... ot

Ranunculacex ...... 84

Rantunculus ....... 8

Reed ............. is

Ribes ............

Rocket ........... s6

Rosacere ........... st

Rubiacer …........ 94

Russula .......... 10.5

Sagittaria ........ $\tau$

Salicacere

Salix .......... s.

Salvia .......... 93

Sandwort ............ :

Sanicula .............. 91

Sarracenia ............

Sarraceniacex ....... so

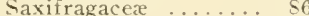

Scleranthus .......... 8

Schizophyllum ........ 107

Scirpus .......... $\%$

Scleria ...........

Scleroderma ........ 119

Sclerodermacex ..... 119

Scrophularia ........ 93

Scrophulariacese ..... 93
Serlge .........

Selaginella .......

Sielagincllaccre ...... in

Senecio .......... 少

Serapias .......... -1

Setaria ............

Shatbush ...........

Sideranthus ........

silene.$\ldots \ldots \ldots \ldots \ldots$ s. st

Sisymbrium .......... at

Suilax ........

Solanacer ........

Solanum ..........

Solca ................

Solidago ..........

Sparassis ......... 11.

Spathularia ........ 116

speedwell ........... !)

Spergula ...........

Spike Rusi ........

Spiraea ............

Spiranthes ..........

Sporobolus ....... i

Stipa ............

Stropharia .......... 11

Sweet Alyssum .......

Tephrosia ........ n

Teucrium .......... 99

Thelephoraceæ ....... 114

Thlaspi .............

Tremella ......... 11.5

Tremellacere .......... 117

Tremellodon ....... 116

Tricholoma ......... 101

Tridens

Triosteum ......... 94

Trollius $\ldots \ldots \ldots \ldots \ldots$ s

Tumble Mustard .... s.

Twayblade $\ldots \ldots \ldots \ldots \ldots$.

Tylostoma ........ 11

Itmus .........

T'mbelliferæ ........ 91

Urnula ......... 11

Ertica ...........

Urticacex ......... $\$ 3$

Vaccinium .........

Valeriana .......... !4

Valerianacex ........ 94

Velvet Grass ....... is

Veratrum .......... si

Verbena ........... 92

Verbenacex .........

Veronica ......... 94

Vetch .......... s9

Vicia.$\ldots \ldots \ldots \ldots \ldots \ldots$

Viola ............ 90

Hiolacere ............. 90

Volvaria .......... 10

Walking Fern ....... if

Wild Chamomile .... 9.

Wild Comfrey ...... 92

II illow ...........

Hyon so 
